\title{
Effect of Organic Inputs on Strength and Stability of Soil Aggregates Associated Organic Carbon Concentration under Rice-Wheat Rotation in Indo-Gangetic Plain Zone of India
}

\author{
R.K. Naresh ${ }^{\text {* }}$, A.S. Panwar ${ }^{2}$, S.S. Dhaliwal ${ }^{3}$, R.K. Gupta ${ }^{4}$, Arvind Kumar ${ }^{5}$, \\ R.S. Rathore ${ }^{6}$, Ashok Kumar ${ }^{7}$, Dipender Kumar ${ }^{8}$, Mohan Lal', Sunil Kumar ${ }^{2}$, Saurabh \\ Tyagi $^{1}$, Vineet Kumar ${ }^{2}$, S.P. Singh ${ }^{7}$, Vikrant Singh ${ }^{9}$ and Nihal Chandra Mahajan ${ }^{1}$ \\ ${ }^{1}$ Department of Agronomy, Sardar Vallabhbhai Patel University of Agriculture \& Technology, \\ Meerut-250110, U.P., India \\ ${ }^{2}$ Indian Institute of Farming System Research, Modipuram-250110, U.P., India \\ ${ }^{3}$ Department of Soil Science, Panjab Agricultural University, Ludhiana, Punjab, India \\ ${ }^{4}$ Borlaug Institute for South Asia (BISA), New Delhi -110 012, India \\ ${ }^{5}$ Rani Lakshmi Bai Central Agricultural University, Jhansi- U.P., India \\ ${ }^{6}$ Uttar Pradesh Council of Agricultural Research, (UPDASP), Lucknow- U.P., India \\ ${ }^{7}$ Department of Soil Science, Sardar Vallabhbhai Patel University of Agriculture \& Technology, \\ Meerut-250110, U.P., India \\ ${ }^{8}$ Department of Agronomy, Panjab Agricultural University, Ludhiana, Punjab, India \\ ${ }^{9}$ Directorate of Sugarcane Development, Aliganj, Lucknow- 226024 (U.P.), India \\ *Corresponding author
}

\section{Keywords}

Tensile strength, Aggregates, Soil organic C, Carbon dynamics, Mean weight diameter.

Article Info

Accepted:

17 September 2017

Available Online:

10 October 2017

\section{A B S T R A C T}

The study aims to elucidate the impact of organic inputs on strength and structural stability of aggregates in a sandy loam soil of Indo-Gangetic Plain Zone of India. Tensile strength, friability and water stability of aggregates, and the carbon contents in bulk soil and in large macro ( $>2 \mathrm{~mm})$, small macro $(0.25-2 \mathrm{~mm})$, micro $(0.053-0.25 \mathrm{~mm})$ and silt+ clay size $(<0.053)$ The aggregate were evaluated in soils with different sources and amounts of organic $\mathrm{C}$ inputs as partial substitution of $\mathrm{N}$ fertilizer. Addition of organic substrates significantly improved soil organic $\mathrm{C}$ contents, but the type and source of input had different impacts. Tensile strength of aggregates decreased and friability increased through organic inputs, with a maximum effect under rice residue-farmyard manure and wheat residue substitution.The aggregate strength and density were lower with organic substitution $(\mathrm{p}<0.05)$ while water retention by aggregates at field capacity was $2-4 \%$ higher with organic inputs. Macro-aggregates $(>0.25 \mathrm{~mm})$ constituted $58-92 \%$ of water stable aggregates and varied significantly among treatments and soil depths. Organic material incorporation improved soil aggregation and structural stability and resulted in higher $\mathrm{C}$ content in macro-aggregates. Higher macro-aggregates in the crop residue- and farmyard manure-treated soils resulted in a higher aggregate mean weight diameter, which also had higher soil organic $\mathrm{C}$ contents. The bulk soil organic $\mathrm{C}$ had a strong relation with the mean weight diameter of aggregates, but the soil organic c content in all aggregate fractions was not necessarily effective for aggregate stability. The soil organic $\mathrm{C}$ content in large macro-aggregates $(2-8 \mathrm{~mm})$ had a significant positive effect on aggregate stability, although a reverse effect was observed for aggregates $<0.25 \mathrm{~mm}$. Partial substitution of nitrogen by organic substrates improved aggregate properties and the soil organic $\mathrm{C}$ content in bulk soil and aggregate fractions, although the relative effect varied with the source and amount of the organic inputs. 


\section{Introduction}

Crop residues, usually considered a problem, when managed correctly can improve soil organic matter dynamics and nutrient cycling, thereby creating a rather favorable environment for plant growth. The intelligent management and utilization of crop residues is essential for the improvement of soil quality and crop productivity under rice-based cropping systems of the tropics. Viable option is to retain residue in the field; burning should be avoided. The major issue is adapting drills to sow into loose residues. Strategies include chopping and spreading of straw during or after combining or the use of disc-type trash drills. Residues rich in lignin and polyphenol contents experience the lowest decay. Decomposition of crop residues occurs at a rapid rate-about $80 \%$ of crop residue $\mathrm{C}$ is lost in the first year-under the warm and humid conditions of the tropics. Factors that control C decomposition also affect the $\mathrm{N}$ mineralization from the crop residues. Decomposition of poor-quality residues with low $\mathrm{N}$ contents, high $\mathrm{C}: \mathrm{N}$ ratios, and high lignin and polyphenol contents generally results in microbial immobilization of soil and fertilizer N. Nutrient cycling in the soil-plant ecosystem is an essential component of sustainable productive agricultural enterprise. Although during the last three decades, fertilization practices have played a dominant role in the rice-based cropping systems, crop residues - the harvest remnants of the previous crop still play an essential role in the cycling of nutrients. Incorporation of crop residues alters the soil environment that in turn influences the microbial population and activity in the soil and subsequent nutrient transformations.

Tensile strength (TS), a fundamental property of aggregates, is a measure of the resistance of the aggregate against breaking forces (Watts and Dexter, 1998), and thus, is highly sensitive to soil management (Blanco-Canqui et al., 2005). High TS of aggregates helps in proper maintenance of soil tilth and pro-vides a stable traction for farm implements, but limits intra-aggregate root growth (Król et al., 2013; Turski, 2002). The friability of the soil, on the other hand, is the tendency of a body of soil to break into smaller pieces under an applied stress or load (Watts and Dexter, 1998). This might be another important physical property of agricultural soils, since the condition of friability is desirable for better tillage and sowing of plants (Dexter and Watts, 2001; Watts and Dexter, 1998). However, data on TS and friability under various combinations of organic and inorganic inputs and their interrelationships with management-induced changes in SOC are scanty (Blanco-Canqui et al., 2005) and none under the intensive rice-wheat system. Water stability of aggregates is the indicator of soil resistance against disintegration (Mohanty et al., 2012), while the size of aggregates indicates the influence of management on soil structural stability. Organic binding agents are mostly responsible for development and stability of macroaggregates $(>0.25 \mathrm{~mm})$, implying the role of organic matter in aggregate stability. The SOC content decreases with intensive cultivation, which corresponds to a decrease in aggregate stability by changing its structure (Król et al., 2013).

\section{Bulk Density (BD)}

Straw management had a large impact on bulk density in the surface layer $(0-10 \mathrm{~cm})$ but not significant in the $10-20 \mathrm{~cm}$ depth. The bulk density under the high-mulch treatment was $58 \%$ lower and that under the low-mulch treatment was $19 \%$ lower than the bulk density under the un-mulched treatment for the $0-3 \mathrm{~cm}$ depth. In the $3-10 \mathrm{~cm}$ depth, bulk density under the high-mulch treatment was only $36 \%$ lower and that under the low-mulch 
treatment was 9\% lower than under the control. Annual application of $16 \mathrm{t} \mathrm{ha}^{-1}$ of rice straw for 3 years decreased bulk density from 1.20 to $0.98 \mathrm{~g} \mathrm{~cm}^{-3}$ in the $0-5 \mathrm{~cm}$ layer on a sandy loam (Lal, 2000). Jill et al., (2011) found that NT than CT in the top $10 \mathrm{~cm}$, but was similar between NT and CT in the 10- to $20-\mathrm{cm}$ depth. Soil BD differed among common rice- based cropping systems with corn, soybean, and winter wheat, but few consistent trends were evident. It appears that, even after 10 years of continuous CT or NT rice production on a silt- loam soil, substantially increased near-surface soil BD has not occurred to the point where soil compaction would be a likely culprit responsible for a reduced early season stand establishment or crop yield differences among rice- based copping systems.

Soil BD is generally greater under reduced tillage, specifically no-tillage (NT), due to machinery traffic and the lack of surface soil disruption and mixing accomplished by annual plowing (Lampurlanés and CanteroMartínez, 2003; Karamanos et al., 2004). Since soil BD has been shown to be inversely related to SOM (Son et al., 2003; Diana et al., 2008), where increasing SOM generally decreases soil BD by adding additional pore space without adding much additional mass, crop rotations with a large frequency of highresidue-producing crops that are managed using cultural practices that return crop residues to the soil could consequently at least maintain a near-surface soil BD that is favorable for gas exchange, water infiltration, and plant growth.

Blanco-Canqui and Lal (2007a) measured bulk density in no till plots that had receiving three levels of wheat straw mulch $(0,8$, and $\left.16 \mathrm{t} \mathrm{ha}^{-1} \mathrm{yr}^{-1}\right)$ for 10 consecutive years on a silt loam in central Ohio. Straw management had a large impact on bulk density in the surface layer $(0-10 \mathrm{~cm})$ but not significant in the 10-20 $\mathrm{cm}$ depth. The bulk density under the high-mulch treatment was 58\% lower and that under the low-mulch treatment was $19 \%$ lower than the bulk density under the unmulched treatment for the $0-3 \mathrm{~cm}$ depth. In the 3-10 cm depth, bulk density under the high-mulch treatment was only $36 \%$ lower and that under the low-mulch treatment was $9 \%$ lower than under the control. Annual application of $16 \mathrm{t} \mathrm{ha}^{-1}$ of rice straw for 3 years decreased bulk density from 1.20 to $0.98 \mathrm{~g} \mathrm{~cm}^{-3}$ in the $0-5 \mathrm{~cm}$ layer on a sandy loam (Lal, 2000). Dalal et al., (2011) also reported the residues management practices had not significant influence on the bulk density of vertisol soil of Australia. Naresh et al., 2016 also reported that mean soil bulk density in the 0 - to $20-\mathrm{cm}$ soil layer of the FIRB with residue retention and ZT with residue retention plots was 12.4 and $6.8 \%$ lower, respectively $(P<0.05)$, than the CT plots. In addition, the FIRB treatment had significantly $(P<0.05)$ lower soil bulk density in the 0 - to $10-$ and $10-$ to $20-\mathrm{cm}$ soil layers than CT by 14.3 and $12.8 \%$, respectively. The changes in bulk density were mainly confined to top $10-15 \mathrm{~cm}$ layer.

Aerobic soil conditions also exist during the dry periods between flooding and heavy precipitation, which stimulates the rapid breakdown of accumulated SOM.

This decline in SOM can, in turn, adversely affect soil productivity, soil quality, and the overall sustainability of rice production (Salinas-Garcia et al., 1997; Amuri and Brye, 2008). The frequent cycling between anaerobic and aerobic conditions can potentially lead to a greater rate of SOM decomposition (Xu et al., 2007), which could essentially increase the BD of the soil. Increasing soil BD over time is a reasonable concern because compacted soil may hinder short-term plant growth and long-term crop yield. 


\section{Water Stable Aggregates (WSA)}

Aggregation is a dynamic process that depends on various agents such as soil fauna, roots, inorganic binding agents and environmental variables. Macro aggregates are gradually bound together by temporary (i.e., fungal hyphae and roots) and transient binding agents (i.e., microbial and plantderived polysaccharides) as the decomposition of soil organic matter takes place (Six et al., 2004). Zero tillage with residue retention improves soil structure compared to conventional tillage (Govaerts et al., 2007). Research on conservation agriculture showed that no-till with stubble retained treatment had more water stable aggregation (Zhang et al., 2009).Retaining crop residues on the soil surface lead to an increase of soil organic carbon, which gives rise to improved soil aggregate stability (Limon-Ortega et al., 2002) and the return of biological diversity to the soil, particularly earthworms (Chan 2001). Mehuys (1988) observed a decrease in MWD of WSA after four years plough till compared with no-till. No tillage increased the proportion of the macro aggregates $(>2 \mathrm{~mm})$ at $0-5 \mathrm{~cm}$ but not at $5-15 \mathrm{~cm}$ depth. The majority of SOC and SON storage under both CT and NT was observed in the largest aggregate size fractions (>2 mm, $250 \mathrm{~mm}$ to $2 \mathrm{~m}$.

Aulakh et al., 2013 showed total WSA after 2 years of the experiment in $0-5 \mathrm{~cm}$ soil layer of CT system, $\mathrm{T}_{2}$ and $\mathrm{T}_{4}$ treatments increased total WSA from $71 \%$ in control $\left(\mathrm{T}_{1}\right)$ to 79 and $81 \%$ without $\mathrm{CR}$, and to $82\left(\mathrm{~T}_{6}\right)$ and $83 \%\left(\mathrm{~T}_{8}\right)$ with CR. The corresponding increase of total WSA under CA system was $75 \%$ in control $\left(\mathrm{T}_{9}\right)$ to $81\left(\mathrm{~T}_{10}\right)$ and $82 \%\left(\mathrm{~T}_{12}\right)$ without $\mathrm{CR}$ and $83\left(\mathrm{~T}_{14}\right)$ and $85 \%\left(\mathrm{~T}_{16}\right)$ in with $\mathrm{CR}$. Naresh et al., (2012) showed significant effects of NT and residue retention on soil aggregate stability in western Uttar Pradesh under an alternative wheat production system.
The capillary-wetted soil aggregates did not show any clear trends across the treatments. Das et al., (2014) observed that a large reduction (50-75\%) in MWD was observed upon slaking, more in case of inorganic $\mathrm{N}$ treatments. Variation in MWD of capillarywetted aggregates was also less $(3.5-4.5 \mathrm{~mm})$. Treatment $\mathrm{T}_{7}$ had significantly higher MWD in all the layers $(3.9-4.6 \mathrm{~mm})$, while rest of the treatments was similar and not different from $\mathrm{T}_{1}$. However, the MWD of slaked aggregates showed larger variations, and the treatments differences were large. In the layer 0-7.5 cm, treatments $\mathrm{T}_{4}, \mathrm{~T}_{6}, \mathrm{~T}_{7}$ and $\mathrm{T}_{8}$ had significantly higher MWDs of slaked aggregates. At $7.5-15$ and $15-30 \mathrm{~cm}$, the values were significantly higher in $T_{7}$ and $T_{8}$. Rests of the treatments were comparable, although significantly higher than (7.5-15 $\mathrm{cm})$ or similar to $(15-30 \mathrm{~cm}) \mathrm{T}_{1}$.

Mazumdar et al., (2015) found that he MWD was significantly higher in plots receiving $50 \% \mathrm{NPK}+50 \% \mathrm{~N}$ through FYM in rice $(1.36$ $\mathrm{mm}), 100 \% \mathrm{NPK}$ in wheat or $50 \% \mathrm{NPK}+50 \%$ $\mathrm{N}$ through CR in rice $(1.28 \mathrm{~mm}), 100 \% \mathrm{NPK}$ in wheat or $50 \% \mathrm{NPK}+50 \% \mathrm{~N}$ through GM in rice $(1.29), 100 \%$ NPK in wheat $(1.18 \mathrm{~mm})$ as compared to control $(0.89 \mathrm{~mm}$. Naresh et al., (2016) revealed that the small macroaggregates accounted for $>30 \%$ of the total aggregates (mean of both main plots) in the surface soil layer. Silt- plus clay-sized aggregates comprised the greatest proportion of the whole soil, followed by the small macro-aggregates. The amount of waterstable large and small macro-aggregates in the FIRB and ZT plots were significantly higher than in the CT plots in the $0-$ to $5-\mathrm{cm}$ soil layer. These differences may be attributed to the different planting systems. A reduced presence of macro aggregates $(>0.25 \mathrm{~mm})$ under TT was partly due to excessive tillage and heavy traffic, which hindered the soil biological activity (Tisdall and Oades, 1979). Bappa Das et al., (2014) revealed that the 
increased amounts of large ( $>2 \mathrm{~mm})$ macroaggregate fractions in NPK + GR (rice) + FYM (wheat) and NPK + CR (rice and wheat) are associated with the very large MWD in these treatments. Similar trends are observed in other organic treatments, with a large amount of small macro-aggregate fractions, along with large macro-aggregates. A higher amount of silt- and clay-sized fractions was observed in the control (43.84\%). Song et al., (2016) observed that zero tillage and straw incorporation also increased the mean weight diameter and stability of the soil aggregates.

\section{Tensile strength of aggregates}

Aggregate strength decreases with increase in SOC, initially at a faster rate and then gradually. The tensile strength was the highest in the unfertilized plots. Due to the low amount of SOC, the air-dry aggregates from the unfertilized plots had increased internal friction between the particles upon drying (Schjonning et al., 1994), and a large amount of readily dispersible clay was available for internal crust formation, cementation of particles and aggregates (Elmholt et al., 2008). The tensile strength of aggregates was the lowest in the plots with the addition of either rice-wheat or green gram crop residue. The decrease in the strength of air-dry aggregates with the increase in organic inputs agrees with other studies (Arthur et al., 2012; Schjonning et al., 2007), but differs from a few (Bartoli et al., 1992). Organic matter helps in particle orientation to form aggregates and also reduces the amount of non-complexed clay for cementation upon drying of the aggregates (Schjonning et al., 2012). Cambardella and Elliott, (1993) reported that soil inversion and disruption by tillage in control and NPK treatments, exposed the protected organic matter to soil organisms, accelerate decomposition and thus affect the average size and stability of soil aggregates. Six et al., (2000) found that micro- aggregates within macro-aggregates accounted for only $27 \%$ of the macroaggregate weight in CT, compared with $47 \%$ of the macro-aggregate weight in NT. Hence, the formation of new micro-aggregates within macro-aggregates was reduced by a factor of about 2 (27\% vs. $47 \%)$ in CT compared with NT. In addition, the concentration of intramicro-aggregate POM-C was three-fold greater in NT compared with $\mathrm{CT}$ while the concentration of inter-micro-aggregate POM$\mathrm{C}$ (i.e., POM-C held within macro-aggregates but not within micro-aggregates) was twofold greater in CT compared with NT. Singh et al., (2007) revealed that the added organics could supply additional fresh organic residues (water soluble and hydrolysable substrates) and $\mathrm{C}$ to the soil resulting in production of microbial polysaccharides that increase aggregate cohesion which could explain the observed progressive increase in aggregate stability to mechanical breakdown.

Six et al., (2000) found that the increase in total fine iPOM (i.e., inter- plus intra-microaggregate iPOM) alone accounted, on average, for $21 \%$ of the total $\mathrm{C}$ difference between NT and CT for temperate climatic condition. Kong et al., (2005) revealed that the addition of organic inputs substantially increased both the fractions, although no preferential accumulation of $\mathrm{C}$ could be identified. However, larger ${ }_{\mathrm{m}} \mathrm{M}-\mathrm{C}$ in organic treatments, especially with GR (rice)-FYM (wheat) is indicative of scope of long-term $\mathrm{C}$ protection within aggregates, which may be a possible indicator of $\mathrm{C}$ sequestration. Das et al., (2014) found that the density, tensile strength and friability of aggregates increased with soil depth but decreased with additional organic inputs. Treatment $\mathrm{T}_{1}$ had the highest aggregate densities $\left(1.82-1.91 \mathrm{Mg} \mathrm{m}^{-3}\right)$ and strengths $(127.2-171.6 \mathrm{kPa})$, but the lowest friability $(0.10-0.15)$. The lowest density was recorded in $\mathrm{T}_{7}$ and $\mathrm{T}_{8}$, which was significantly higher than $T_{1}$, in all the layers. 
Treatment $\mathrm{T}_{4}$ had similar effect as in $\mathrm{T}_{7}$ and $\mathrm{T}_{8}$ in $0-7.5$ and $7.5-15.0 \mathrm{~cm}$ layers. Effect of inorganic fertilizers was not significant except in $\mathrm{T}_{3}$ at $0-7.5 \mathrm{~cm}$. The TS was minimum in $\mathrm{T}_{4}$ $(85.6-124.0 \mathrm{kPa})$, T6 $(84.2-123.3 \mathrm{kPa}), \mathrm{T}_{7}$ $(80.3-117.6 \mathrm{kPa})$ and $\mathrm{T}_{8}(79.6-117.2 \mathrm{kPa})$, while effect of inorganic $\mathrm{N}$ was significant in 0-7.5 cm layer only. Similarly, the effect of SPM in reducing the density and strength of aggregates was restricted to $0-7.5 \mathrm{~cm}$ layer. Friability of aggregates improved significantly with addition of organic inputs and was most evident in $\mathrm{T}_{7}(0.44,0.36$ and 0.30 at $0-7.5,7.5-15.0$ and $15-30 \mathrm{~cm}$, respectively). Treatments with inorganic $\mathrm{N}$ only $\left(T_{1}\right.$ and $\left.T_{2}\right)$ had no apparent effect on the friability. Substitution of inorganic $\mathrm{N}$ by organic sources improved water retention by aggregates although it varied among soil layers and size of aggregates.

\section{Aggregation and structural indices}

The role of soil organic matter in aggregate stability is summarized in Figure 2. Straw incorporation helps the formation and stability of aggregates through increase in microbial cells, and excretes microbial products and decomposition products released during the death of the microorganisms (Lynch and Elliott, 1983). The soil organic matter in turn is protected within aggregates for decomposition (Dalal and Bridge, 1996).

The amount and chemical composition of organic residues, temperature, and moisture conditions are the major factors determining aggregation in soil (Prasad and Power, 1991). Thus, easily decomposable plant residues such as green manure and grain legume residues provide transient and temporary aggregate stabilizing agents, while cereal crop residues provide persistent aggregate stabilizing agents (Elliott and Lynch, 1984). Chaudhary and Ghildhyal (1969) obtained a close relation $(r=0.76)$ between organic $C$ increased by organic materials addition and aggregate stability of soil under wetland rice. Likewise, Elliott and Lynch (1984) found that the effect of straw on aggregation in a silt loam soil decreased with increasing straw $\mathrm{N}$ content in the range of 0.25 to $1.09 \%$.

In a rice-wheat cropping system on a loamy sand soil, incorporation of wheat straw over a 5 -year period in rice promoted formation of soil aggregates, particularly 1-2 mm size, and mean weight diameter. A mixed application of green manure and crop residues was more effective compared to their separate applications. Similarly, in a long-term experiment (1981-1990) on rice-rice rotation in China, Liu and Shen (1992) noted that application of crop residues promoted aggregation. The contents of microaggregates $(0.25-1.0 \mathrm{~mm})$ were increased from $10.9 \%$ in inorganic fertilizer treatment to $12.1 \%$ in milk vetch green manure and to $13.6 \%$ in green manure plus rice straw treatment. The effect of crop residues on aggregation also depends on the aggregation potential of the soil.

Datta et al., (1989) have shown that when clay clayey soil significantly increased water stable aggregates $>0.25 \mathrm{~mm}$. Total organic C also increased, which resulted in a marked increase of macro-pores as well as the aggregate size in the $2.0-0.84 \mathrm{~mm}$ size fractions (El Samanoudy et al., 1993). In friable self-mulching clay of the vertisol group, 34 years of either stubble burning or incorporation had, however, little effect on soil structure (Dexter et al., 1982).

The nature of plant material also plays an important role in the development of soil structure. For example, Dhoot et al., (1974) recorded the highest percentage of waterstable aggregates in pearl millet-amended soil followed by rice straw or wheat straw and sesbania green manure. 
Singh et al., (2007) have shown that addition of various organic manures along with inorganic fertilizers in rice-wheat system improved the aggregation status of the soil. Aggregate ratio varied significantly with treatments. Compared with the control, treatments where more organic matter was added either through FYM, CR and GM maintained a greater fraction of macroaggregate. Yang et al., (2014) noticed that long-term winter planted green manure (Chinese milk vetch) substantially improved the SOC content and the $\mathrm{C}: \mathrm{N}$ ratio coupled with redistribution of the macro-aggregates into micro-forms.

\section{Size composition of the soil aggregates}

Li et al., (2007) have shown that the aggregated $\mathrm{C}$ concentration of coarse macroaggregates were higher (both under CT, RT and ZT) to those of the meso-aggregates and micro-aggregates. The macro-aggregates were generally formed by soil particles held together by organic residues. Moharana et al., (2012) observed that the highest values of TOC (11.48 $\left.\mathrm{g} \mathrm{kg}^{-1}\right)$ and WBC (7.86 $\left.\mathrm{g} \mathrm{kg}^{-1}\right)$ were maintained in FYM treated plot, while the highest values of LBC $\left(1.36 \mathrm{~g} \mathrm{~kg}^{-1}\right)$ and MBC (273 mg kg-1) were found in FYM + NPK. The magnitude of change in pools of SOC in sub-surface $(15-30 \mathrm{~cm})$ soil was low as compared to the surface soil $(0-15 \mathrm{~cm})$. Das et al., 2014 found that the aggregate strength and density were lower with organic substitution $(\mathrm{p}<0.05)$ while water retention by aggregates at field capacity was $2-4 \%$ higher with organic inputs. Macro-aggregates $(>0.25 \mathrm{~mm})$ constituted $58-92 \%$ of water stable aggregates and varied significantly among treatments and soil depths. Organic material incorporation improved soil aggregation and structural stability and resulted in higher $\mathrm{C}$ content in macroaggregates. Chaudhary et al., 2014 reported that compared to conventional tillage, water stable macro-aggregates in conservation tillage (reduced and zero-tillage) in wheat coupled with direct seeded rice (DSR) was increased by $50.13 \%$ and water stable microaggregates of the later decreased by $10.1 \%$ in surface soil. Residue incorporation caused a significant increment of $15.65 \%$ in total water stable aggregates in surface soil $(0-15 \mathrm{~cm})$ and $7.53 \%$ in sub-surface soil $(15-30 \mathrm{~cm})$. In surface soil, the maximum (19.2\%) and minimum $(8.9 \%)$ proportion of total aggregated carbon was retained with $>2 \mathrm{~mm}$ and $0.1-0.05 \mathrm{~mm}$ size fractions, respectively. According to Edwards and Bremner (1967), the only highly stable aggregates are fine sand- and silt-sized micro-aggregates $(<250 \mu \mathrm{m})$ consisting of clay-polyvalent metal-organic matter complexes (Figure 2a). Micro-aggregates are formed by bonding of $\mathrm{C}-\mathrm{P}-\mathrm{OM}$ clay sized units, where $\mathrm{C}$ : clay particle, $\mathrm{P}$ : polyvalent metal $(\mathrm{Fe}, \mathrm{Al}, \mathrm{Ca})$ and $\mathrm{OM}$ : organo-metal complex, and are represented as $\left[(\mathrm{C}-\mathrm{P}-\mathrm{OM})_{x}\right]_{y}$.

Tisdall and Oades (1982) reported that implicitly understood that aggregates are sequentially formed, i.e. micro-aggregates are first formed free and then serve as the building blocks for the formation of macroaggregates. Oades (1984) postulated that the roots and hyphae holding together the macroaggregate form the nucleus for microaggregate formation in the center of the macro-aggregate. Since roots and hyphae are temporary binding agents, they do not persist and decompose into fragments (Figure 2b). These fragments coated with mucilage are produced during decomposition become en crusted with clays resulting in the inception of a micro-aggregate within a macro-aggregate.

Kumar et al., (2016) further argued that the proportion of macro-aggregates in the size class of 0.25 to $>2 \mathrm{~mm}$ was higher as compared to micro-aggregate in the size class $0.11-0.25 \mathrm{~mm}$. Among the macro-aggregates, 
$0.25-0.50 \mathrm{~mm}$ fraction constituted the greatest proportion followed by $0.5-1.0,1.0$ 2.0 , and $>2 \mathrm{~mm}$ fraction constituted the least proportion in both $0-5-$ and $5-15-\mathrm{cm}$ soil layers under both CT and CA practices. Mazumdar et al., (2015) also found that Macro-aggregates constituted 37-60\% of total WSA and the proportion of micro-aggregates ranged from 19 to $30 \%$. Addition of FYM, wheat straw and green manure increased macro-aggregate fractions, with a concomitant decrease in micro-aggregate fractions. Among the macro-aggregates, 0.25$0.50 \mathrm{~mm}$ fraction constituted the largest proportion and had higher $\mathrm{C}$ density compared to micro-aggregates. Song et al., (2016) reported that compared to conventional tillage, the percentages of $>2 \mathrm{~mm}$ macro aggregates and water-stable macroaggregates in rice-wheat double- conservation tillage (zero-tillage and straw incorporation) were increased $17.22 \%$ and $36.38 \%$ in the 0 $15 \mathrm{~cm}$ soil layer and $28.93 \%$ and $66.34 \%$ in the $15-30 \mathrm{~cm}$ soil layer, respectively. In surface soil $(0-15 \mathrm{~cm})$, the maximum proportion of total aggregated carbon was retained with $0.25-0.106 \mathrm{~mm}$ aggregates, and rice-wheat double-conservation tillage had the greatest ability to hold the organic carbon (33.64 $\mathrm{g} \mathrm{kg}^{-1}$ )

Naresh et al., (2017) it is evident that the MBC contents in both surface and sub-surface soil were significantly higher in plots receiving $50 \% \mathrm{RDN}$ as $\mathrm{CF}+50 \% \mathrm{RDN}$ as FYM $\left(\mathrm{F}_{5}\right)$ and $100 \%$ RDN as FYM $\left(\mathrm{F}_{4}\right)$ treated plots compared to $100 \% \mathrm{RDN}$ as $\mathrm{CF}$ $\left(\mathrm{F}_{3}\right)$ fertilizer and unfertilized control plots. The values of MBC in surface soil varied from $116.8 \mathrm{mgkg}^{-1}$ in unfertilized control plot to $424.1 \mathrm{mgkg}^{-1}$ in integrated nutrient use of $50 \% \mathrm{RDN}$ as $\mathrm{CF}+50 \% \mathrm{RDN}$ as $\mathrm{FYM}\left(\mathrm{F}_{5}\right)$ plots, respectively; while it varied from 106.6 $\mathrm{mgkg}^{-1}$ (control) to $324.9 \mathrm{mgkg}^{-1}(100 \%$ $\mathrm{RDN}$ as $\left.\mathrm{FYM} \mathrm{F}_{5}\right)$ in sub-surface $(15-30 \mathrm{~cm})$ soil layer. The values of $\mathrm{MBC}$ increased by
58.4 and $72.5 \%$ under $50 \% \mathrm{RDN}$ as $\mathrm{CF}+50 \%$ RDN as $\mathrm{CF}$ foliar $\left(\mathrm{F}_{5}\right)$ treatment in surface soil over control. While, there were 14.5 and $43.4 \%$ increase of $\mathrm{MBC}$ over $100 \% \mathrm{RDF}$ as $\mathrm{CF}\left(\mathrm{F}_{3}\right)$ fertilizer, respectively. The highest value of MBC due to integrated use of FYM and RDN fertilizer might be due to higher turn-over of root biomass produced under $50 \% \mathrm{RDN}$ as $\mathrm{CF}+50 \% \mathrm{FYM}$ treatment.

\section{Aggregate-associated organic carbon}

Das et al., (2014) revealed that the long term application of organics increased aggregate associated $\mathrm{C}$ as compared in all aggregate size fractions; the highest increase was observed in plots receiving NPK and FYM in combination. Arthur et al., (2012) also indicate that post-tillage consolidation of soils developing into compact and denser aggregates is significantly reduced through addition of organic inputs. However, variation among the treatments reveals different degrees of organic matter decomposition to influence aggregate densities. Addition of organics also reduces strength of air-dry aggregates, and the effect is most significant with crop residue addition. Das et al., 2014 found stability of aggregates is expressed by the mean weight diameter of the size range, which is proportional to the amount of larger water stable aggregates. Increased amounts of large $(>2 \mathrm{~mm})$ macro-aggregate fractions in $\mathrm{NPK}+\mathrm{GR}$ (rice) + FYM (wheat) and NPK + $\mathrm{CR}$ (rice and wheat) are associated with the very large MWD in these treatments. The strong linearity between the MWD and SOC indicates that long-term application of organic amendments can impart a significantly higher stability to the aggregates and thus, highly improves the soil structure (Abrishamkesh et al., 2011).

Six et al., (2000) revealed that the rate of macro- and micro-aggregate formation, stabilization and degradation are directly 
related to the dynamics of POM-C. Following the incorporation of fresh residue in the soil, soil fungi and other soil microorganisms utilize the more easily available $\mathrm{C}$ and produce mucilage's resulting in the formation of macro-aggregates around coarse $(>250 \mu \mathrm{m})$ intra-aggregate POM (coarse iPOM). Coarse iPOM is further decomposed and fragmented into fine $(53-250 \mu \mathrm{m}) \mathrm{iPOM}$. The fine iPOM and associated mucilage's become encrusted with minerals to form the stabilized organic core of a newly developed micro-aggregate within macro-aggregate (Figure 3).The latter process is cut short if the macro-aggregate turnover is increased by disturbance, resulting in a reduced sequestration of $\mathrm{C}$ (Six et al., 2000a). Schjønning et al., (2012) observed that low organic matter in the zero-N plots increases the strength of air-dry aggregates due to increased internal friction between the particles upon drying. Organic matter plays the pivotal role in orienting soil particles to form aggregates and also by reducing the amount of non-complexed clay available for cementation upon drying of aggregates. Mazumdar et al., (2015) reported that incorporation of organic manures induces decomposition of organic matter where roots, hyphae and polysaccharides bind mineral particles into micro-aggregates and then these micro-aggregates bind to form $\mathrm{C}$ rich macroaggregates. This type of $\mathrm{C}$ is physically protected within macro-aggregates.

Continuous incorporation of crop residues could replenish the fast depletion of soil organic matter through continuous turnover of soil under intensive agriculture, thereby improving stability of aggregates. In agreement with increase in macro-aggregates by addition of rice straw and FYM in sandy loam soil in northwest India (Benbi and Senapati, 2010) and through FYM in clay soil of central India (Bandyopadhyay et al., 2010); increase in slaking-resistant macro-aggregates through manure in silt loam soil in Canada
(Aoyama et al., 1999); and wheat straw in central Ohio (Blanco-Canqui and Lal, 2007). Greater amount of water stable aggregates $>0.25$ was also reported by Karami et al., (2012) under similar kinds of amendment (rice husk and wheat straw, cow manure) and climate (semi-arid) as in the present study. The LM $(>2 \mathrm{~mm})$ fractions are also significantly in higher proportion at $0-7.5 \mathrm{~cm}$ layer with crop residue incorporation indicating greater soil microbial activities through freshly available $\mathrm{C}$ (Mikha and Rice, 2004). Green gram residue in rice has less impact on aggregate stability (e.g. P.K. Bandyopadhyay et al., 2010), but becomes effective when combined with FYM in wheat. Higher amount of macro-aggregates through organic amendments and a lower proportion of micro-aggregates imply that addition of organics supports formation of macroaggregates through binding of microaggregates (Huang et al., 2010).

\section{Carbon content and aggregate stability}

A higher amount of MicAC $(<0.25 \mathrm{~mm})$ that was incarcerated by $\mathrm{NPK}+\mathrm{GM}(52.3 \%)$ treatment may be attributed to the nature of the lignin present or the polysaccharides originating from GM that might not have the same ability to bind particles together as those from FYM and PS. Again, the efficiency of the polysaccharides as binding aggregates depends on their location within the aggregated particle (Abiven et al., 2007).

Shrestha et al., (2007) found similar variations under different land uses in Nepal. Upon sieving, $\mathrm{C}$ in different size fractions were exposed more and oxidized extra $\mathrm{C}$ during chemical reaction for $\mathrm{C}$ estimation, than that resulted in bulk soil, which could make differences between them. This possibility cannot be ruled out as the 'silt+ clay' C fraction recovered $\mathrm{N} 50 \%$ of soil $\mathrm{C}$ under different treatments. 
Dou et al., (2008) revealed that reduced tillage practices allow $\mathrm{C}$ to build-up in the plow layer by enhancing soil aggregation and reducing oxidation. According to Lewis et al., (2011), increasing tillage intensity could reduce $\mathrm{KMnO}_{4}-\mathrm{C}$ levels in soils as a result of destruction of soil macro-aggregates and elevated respiration. Lower amount of $\mathrm{KMnO}_{4}-\mathrm{C}$, hence is likely under CT due to increased soil disturbances subjecting aggregated protected SOC fraction to rapid decomposition via oxidation.

Particulate organic matter (POM, $>53 \mu \mathrm{m})$ represents a significant proportion of the slow pool of SOM and is important in maintaining the stability of macro-aggregates $(>250 \mu \mathrm{m})$. POM contains about $20-45 \%$ of total organic carbon and $13-40 \%$ of total soil N (Cambardella and Elliott, 1992).

POM and microbial biomass are considered as biologically active fractions of SOM and are sensitive indicators of managementinduced changes in the fate of crop residues and the turnover of SOM constituents. Melero et al., (2011) reported that the magnitude of changes in SOC fractions between conservation tillage practices (ST and NT) and $\mathrm{CT}$ ranged in the decreasing order of CPOM-C (17.2-41.8\%) > cumulative $\mathrm{C}_{\min }$ $(6.6-22.5 \%)>\mathrm{KMnO}_{4}-\mathrm{C}(2.6-4.8 \%)$.

These suggest that tillage induced changes were sensitively reflected by the changes in physical (CPOM-C), chemical $\left(\mathrm{KMnO}_{4}-\mathrm{C}\right)$, and biological (cumulative $\mathrm{C}_{\min }$ ) $\mathrm{SOC}$ fractions and therefore, can be used to estimate early changes in SOC dynamics.

Bhattacharyya et al., 2013 found that small macro-aggregates accounted for $>30 \%$ of the total aggregates (mean of both main plots) in the surface soil layer. Silt- plus clay-sized aggregates comprised the greatest proportion of the whole soil, followed by the small macro-aggregates.

\section{Soil organic matter pattern}

Soil organisms use residues as a source of energy and nutrients, thereby releasing $\mathrm{CO}_{2}$, inorganic compounds, and recalcitrant molecules, which contribute to the formation of soil humus. Decomposition of crop residues releases about $55-70 \%$ of the $\mathrm{C}$ to the atmosphere as $\mathrm{CO}_{2}, \quad 5-15 \%$ is incorporated into microbial biomass, and the remaining C (15-40\%) is partially stabilized in soil as new humus (Stott and Martin, 1989). Because the amount of carbon in soils is large and changes rather slowly, the implications of a particular management system on the soil carbon may be apparent only after several years to decades. Numerous calculations have been made of the amount of residues needed to maintain organic matter at a particular level (Paustian et al., 1997).

Incorporation of both residues increased organic $\mathrm{C}$ and total $\mathrm{N}$ compared to removal or burning of straw (Dhiman et al., 2000). When only rice or wheat straw was incorporated, organic $\mathrm{C}$ content did not differ significantly from removal or burning of straw. Rice straw was more effective in increasing total $\mathrm{N}$ content of soil than wheat straw. Raju and Reddy (2000) reported that in rice-rice rotation, incorporation of rice straw to supply $25 \%$ of the recommended $\mathrm{N}$ fertilizer dose for rainy season crop for 6 years significantly increased organic C content from $0.98 \%$ in straw removal treatment to $1.29 \%$. Sharma (2001) reported that organic C content increased from $0.56 \%$ in straw removal to $0.66 \%$ when both the residues were incorporated for 2 years in rice-wheat rotation.

Burning and removal of crop residues were at par for their effect on organic $\mathrm{C}$ content. In another long-term study, Yadvinder-Singh et al., (2004a) reported that wheat straw incorporation in rice increased organic $\mathrm{C}$ 
content from $0.40 \%$ in straw removal treatment to $0.53 \%$ in straw incorporation treatment after 12 years of experimentation on a loamy sand soil. The values after 6 years were 0.38 and $0.49 \%$, respectively, suggesting smaller increases in organic $\mathrm{C}$ between 6 and 12 years than during $0-6$ years.

Naklang et al., (1999) observed no significant effect of rice straw incorporation for 3 years on total and labile $\mathrm{C}$ content of a sandy soil. In a rice-barley rotation under dryland conditions in northern India, Kushwaha et al., (2000) observed a significant increase (28\%) in soil organic carbon and $33 \%$ increase in total $\mathrm{N}$ with the incorporation of crop residues compared to their removal after one annual cycle. It was suggested that for soil fertility enhancement in dryland agro-ecosystems, postharvest retention of crop residues (20$40 \%$ aboveground biomass) of previous crop and its incorporation in soil through minimum tillage in the succeeding crop should be followed.

Application of rice straw at $10 \mathrm{t} \mathrm{ha}^{-1}$ to an upland sandy soil caused a net increase in soil $\mathrm{C}$ by $0.31 \mathrm{t} \mathrm{ha}^{-1}$ over no rice straw treatment (Ono, 1989). The increase in $\mathrm{C}$ represented $8 \%$ of the $\mathrm{C}$ applied in rice straw. At higher rates of straw addition, the net increase in soil $\mathrm{C}$ was increased but the percent $\mathrm{C}$ increase did not change significantly. The soil $\mathrm{C}$ buildup in the soil was significantly positively correlated with $\% \mathrm{~N}$ and negatively correlated with C: N ratio. Adiningsih (1984) reported that incorporation of rice straw into the soil for 4 years increased the soil organic matter content from 2.4 to $3.9 \%$ and total $\mathrm{N}$ content from 0.25 to $0.33 \%$ over straw removal in Indonesia. In China, Liu and Weng (1991) found that returning rice straw to rice fields for 2 years usually increased soil organic matter content by 0.03 to $0.05 \%$. From a longterm field experiment in Japan, Gotoh et al., (1984) estimated that 13 to $25 \%$ of the organic matter returned to soil through rice straw was incorporated into the soil organic matter in a slowly permeable grey lowland soil. In a long-term study on a rice-wheat cropping system in northwestern India, the incorporation of crop residues along with green manure in rice increased soil organic carbon and total $\mathrm{N}$ contents as compared to straw removal, but the increase was almost similar to that when crop residues were applied alone. These data suggested little effect of green manure on soil organic matter content in semi-arid climates, particularly in coarse-textured soils Ponnamperuma (1984).

Naresh et al., (2015) reported that average SOC concentration of the control treatment was $0.54 \%$, which increased to $0.65 \%$ in the RDF treatment and $0.82 \%$ in the RDF+ FYM treatment. Compared to $\mathrm{F}_{1}$ control treatment the $\mathrm{RDF}+\mathrm{FYM}$ treatment sequestered 0.33 $\mathrm{Mg} \mathrm{C}$ ha $^{-1} \mathrm{yr}^{-1}$ whereas the NPK treatment sequestered $0.16 \mathrm{Mg} \mathrm{C} \mathrm{ha}^{-1} \mathrm{yr}^{-1}$. Naresh et al., (2017) found that the quantities of SOC at the $0-400 \mathrm{~kg}$ of soil $\mathrm{m}^{-2}$ interval decreased under ZT without residue $\left(\mathrm{T}_{1}\right)$, PRB without residue $\left(\mathrm{T}_{4}\right)$ and Conventional tillage $\left(\mathrm{T}_{7}\right)$ treatments evaluated. Stocks of SOC in the top $400 \mathrm{~kg}$ of soil $\mathrm{m}^{-2}$ decreased from 7.46 to $7.15 \mathrm{~kg}$ of C $\mathrm{m}^{-2}$ represented a change of $-0.31 \pm 0.03 \mathrm{~kg}$ of $\mathrm{C} \mathrm{m} \mathrm{m}^{-2}$ in $\mathrm{T}_{1}, 8.81$ to $8.75 \mathrm{~kg}$ of $\mathrm{C} \mathrm{m}^{-2}$ represented a change of $-0.06 \pm 0.05 \mathrm{~kg}$ of $\mathrm{C}$ $\mathrm{m}^{-2}$ in $\mathrm{T}_{4}$, and 5.92 to 5.22 of $\mathrm{C} \mathrm{m}^{-2}$ represented a change of $-0.70 \pm 0.09 \mathrm{~kg}$ of $\mathrm{C}$ $\mathrm{m}^{-2}$ in $\mathrm{T}_{7}$ between 2000 and 2016 (Table 1).

\section{Soil Organic Carbon Distribution}

Majumder et al., (2008) reported $67.9 \%$ of C stabilization from FYM applied in a ricewheat sys-tem in the lower Indo-Gangetic plains. It is well recognized that improved management practices promote soil carbon sequestration, and thus increase soil carbon storage (Lu et al., 2009). Soil C: N ratio was significantly influenced by tillage system, 
residues and $\mathrm{N}$ rates, being decreased with chisel treatment and increased residues and $\mathrm{N}$ rates $\left(75-150 \mathrm{~kg} \mathrm{ha}^{-1}\right)$ in both years. The $\mathrm{C}: \mathrm{N}$ ratio is related to the changes in soil $\mathrm{C}$ and $\mathrm{N}$ contents. The $\mathrm{C}$ : $\mathrm{N}$ ratio of soil is related to the patterns of $\mathrm{N}$ immobilization and mineralization during organic matter decomposition by microorganisms and is negatively correlated with net $\mathrm{N}$ mineralization (Van Den Bossche et al., 2009). Alijani et al., 2012 revealed that the soil with chisel treatment had about 8 and $15 \%$ more soil organic carbon (SOC) and total $\mathrm{N}$ than moldboard plow treatment, respectively. Incorporation of increased amounts of corn residues and a higher $\mathrm{N}$ rate reduced $\mathrm{C}: \mathrm{N}$ ratios in the chisel treatment in both years.

According to Chatterjee and Lal (2009), crop residues are left on the soil surface under NT and ST practices whereas residues are incorporated in the soil during tillage under $\mathrm{CT}$, thereby favoring increased mineralization of CPOM-C by soil microbes under the latter. Similarly, tillage induces the disruption of soil aggregates, and, increased exposure of soil aggregate protected $\mathrm{CPOM}-\mathrm{C}$ to microbial decomposition following the collapse of aggregates by increased tillage intensity (CT) as compared with reduced tillage (ST and NT) may have contributed to the low levels of CPOM-C under CT treatment (Mikha and Rice, 2004).

Chaudhary et al., 2014 also found that DSR combined with zero tillage in wheat along with residue retention $\left(T_{6}\right)$ had the highest capability to hold the organic carbon in surface (11.57 $\mathrm{g} \mathrm{kg}^{-1}$ soil aggregates) with the highest stratification ratio of SOC (1.5). Plante and McGill (2002a) suggested that the relationship between physical protection of SOM and the turnover of macro-aggregates differs for fresh residue versus stabilized SOM. For stabilized SOM, the slower the macro-aggregate turnover the higher the protection level. An intermediate aggregate turnover would be optimal for newly incoming fresh residue because a certain aggregate turnover is needed to have aggregate formation and occlusion and subsequent protection of $\mathrm{C}$ within the aggregates. However, we suggest that macroaggregate turnover in most ecosystems is never so slow that it hinders the stabilization of C (Figure 4).

Paudel et al., (2014) showed that, soil organic carbon buildup was affected significantly by tillage and residue level in upper depth of 0 $20 \mathrm{~cm}$ but not in lower depth of $20-40 \mathrm{~cm}$. Higher SOC content of $19.44 \mathrm{~g} \mathrm{~kg}^{-1}$ of soil was found in zero tilled residue retained plots followed by $18.53 \mathrm{~g} \mathrm{~kg}^{-1}$ in permanently raised bed with residue retained plots. Whereas, the lowest level of SOC content of $15.86 \mathrm{~g} \mathrm{~kg}^{-1}$ of soil were found in puddled transplanted rice followed by wheat planted under conventionally tilled plots. Naresh et al., (2015) revealed that the highest SOC stock of $72.2 \mathrm{Mg} \mathrm{C}^{-1}$ was observed in $\mathrm{F}_{4}$ with $\mathrm{T}_{6}$ followed by that of $64 \mathrm{Mg} \mathrm{C}^{-1}$ in $\mathrm{F}_{6}$ with $\mathrm{T}_{2}>$ that in $\mathrm{F}_{3}$ with $\mathrm{T}_{4}\left(57.9 \mathrm{Mg} \mathrm{C} \mathrm{ha}^{-1}\right)>$ $\mathrm{F}_{5}$ with $\mathrm{T}_{1}\left(38.4 \mathrm{Mg} \mathrm{Cha}{ }^{-1}\right)=\mathrm{F}_{7}$ with $\mathrm{T}_{5}$ (35.8Mg C ha ${ }^{-1)}$, and the lowest $(19.9 \mathrm{Mg} \mathrm{C}$ ha $^{-1}$ ) in $F_{1}$ with $T_{7}$. Relatively higher percentage increase of SOC stock was observed in $\mathrm{F}_{4}$ with $\mathrm{T}_{6}$ treatment $(56.3 \mathrm{Mg}$ $\mathrm{Cha}^{-1}$ ) followed by $\mathrm{F}_{6}$ with $\mathrm{T}_{2}(51.4 \mathrm{Mg}$ $\left.\mathrm{Cha}^{-1}\right)$ and $\mathrm{F}_{3}$ with $\mathrm{T}_{1}\left(48.4 \mathrm{Mg} \mathrm{Cha}^{-1}\right)$. Xue et al., (2015) found that over time, CT system generally exhibit a significant decline in SOC concentration due to destruction of the soil structure, exposing SOM protected within soil aggregates to microbial organisms. Ghimire et al., (2012) revealed that $9.89 \%$ greater SOC in $0-50 \mathrm{~cm}$ soil profile under no-tillage than under conventional tillage in a rice-wheat system. The significant fraction of SOC under no-tillage was accumulated in surface soil with $28.3 \%$ greater SOC content in $0-5 \mathrm{~cm}$ 
depth of no-tillage system than that in the conventional tillage system. Pandey et al., (2014) revealed that no-tillage before sowing of rice and wheat could increase SOC by 0.59 $\mathrm{Mg} \mathrm{C} \mathrm{ha}{ }^{-1} \mathrm{yr}^{-1}$. The rate of SOC sequestration due to reduced- or no-tillage management in rice-based systems in South Asia varied from 0- to $2114 \mathrm{~kg} \mathrm{ha}^{-1} \mathrm{yr}^{-1}$ (Bhattacharyya et al., 2012a).

\section{Carbon dynamics}

The combined effects of land use patterns and their changes can influence SOM content considerably, as they exert control on common factors determining the soil system (e.g., quality of biomass input, biomass decomposition rates, and pace of organic matter stabilization) (Gelaw et al., 2014) (Figure 6). It was reported that the SOC pool can be cumulatively affected due to fertilization, tillage, crop rotation, and soil water conservation farming (Hao et al., 2002). Hence, SOC content was found to increase substantially with the application of adequate fertilizer ( $\mathrm{N}$ and $\mathrm{P}$ ) in semiarid southwestern Saskatchewan (Campbell et al., 2000). Many studies have advocated the usage of organic inputs toward achieving better soil quality with elevated SOC content, enhanced agronomic stability, and improved soil structure (Bhattacharyya et al., 2008).

Different types of amendments (compost, green manure, bio-fertilizer, and raw wastes) on planet soil systems not only showed very similar patterns, but were also identified as very dependent on considerable variability (e.g., agricultural techniques, climate, soil type and texture, and material characteristics). Among the numerous changes associated with soil properties, biochemical and microbiological properties have been identified as very sensitive to additional organic inputs by soil modification (Abd ElFattah et al., 2013).
Artificial organic inputs in the form of organic modifications continuously provided various indispensible nutrients to microbial communities due to the slow decomposition kinetics of organic matter (Murphy et al., 2007); such inputs were superior to mineral fertilizer with many known versatile advantages. Application of organic inputs via soil amendment significantly enhanced the cation exchange capabilities due to the negative charge induced by organic carbon (Weber et al., 2007; Kaur et al., 2008): these capabilities are a very important contributor to detainment of various nutrients from organic inputs and for nourishing agricultural plants. Lastly, organic input can also ensure aggregate stability, as the high stability of aggregation provides favorable conditions for mass transfer, retention time of water, root growth, and microbial activity (Carter, 2002).

Continuous application of chemical fertilizers coupled with farmyard manure led to a significant increase in SOC and total $\mathrm{N}$ compared to adjacent fallow land in a eutrochrept soil (Reddy et al., 2003). However, long-term use of inorganic fertilizers (N, P, and $\mathrm{K}$ ) without organic nutrient sources may lead to significant degradation of soil quality and subsequent loss of SOC (Fan et al., 2005). Mozumder and Barrens (2007) opined that excessive use of chemical fertilizers should impose adverse effects on the soil biodiversity which can invariably harm its functioning. Consequently, optimization of chemical fertilization with organic substitution is a better and safer proposition to sustain soil health (Saikia et al., 2015).

Lima et al., (2009) advocated that long-term application of farmyard manure enriches SOM with carbohydrates as well as lignin and lignin-like products. A positive correlation between the soil quality index (SQI), SOM, and crop yield was observed from farm 
compost (D'Hose et al., 2014). Incorporation of municipal solid waste compost (MSWC) and farmyard manure to soil enhanced the SOM by 2.2 and 2 times, respectively (Hemmat et al., 2010).Bhattacharya et al., (2012) reported a significant increase in SOC after enriching typical red and lateritic soil with coal fly ash vermin-compost. Lin et al., (2008) observed a very large 59-63\% increase in SOC after incorporation of green manure in conjunction with industrial waste water. An overall relative increase in the SOC content was achieved under green manuring with Sesbania rostrata, Sesbania aculeate, and green gram residue over fallow in a rice field (Mandal et al., 2003).Yang et al., (2014) noticed that long-term winter planted green manure substantially improved the SOC content and the $\mathrm{C} / \mathrm{N}$ ratio coupled with redistribution of the macro-aggregates into micro-forms.

\section{Crop residue and carbon sequestration}

Duxbury and Lauren (2004) revealed that an average, soil $\mathrm{C}$ stock increased by 1.48 tha $^{-1}$ when residues were added. The total amount of residues added over the period of 7 years was $29.5 \mathrm{t} / \mathrm{ha}$ or $14.75 \mathrm{tC} \mathrm{ha}{ }^{-1}$. Thus, C retention was $10 \%$ of that added or $0.21 \mathrm{t} \mathrm{C}$ $\mathrm{ha}^{-1} \mathrm{yr}^{-1}$. Puget and Drinkwater (2001) in their study with leguminous green manure observed that nearly half of the root derived C was still present in the soil after one growing season in comparison to only $13 \%$ of shootderived Singh and Sidhu (2014) found that zero-till sowing of wheat with rice residue as surface mulch, while maintaining yield, reduces tillage costs and time saving, avoids the need for burning. Dikgwatlhe et al., (2014) further argued that the amount of SOC storage depends on the balance between the quantity and quality of SOM inputs outputs which is largely determined by the combined interaction of climate, soil properties and land use management. Verma and Bhagat (1992) have also recorded the maximum soil buildup of organic carbon under the rice straw chopped and incorporated with animal manure, followed by animal manure and straw mulch, while minimum organic carbon under rice straw burnt and rice straw removed. Less carbon sequestration in bed planting than zero tillage in same level of residue retention in this cropping system might be due to earlier dryness, less microbial population and less decomposition in bed during wheat season. The variation of soil organic carbon sequestration also depends on difference in microbial populace, moisture and temperature fluctuation (Govaerts et al., 2009).

Verma and Pandey, (2013) found that significantly higher organic carbon content was recorded with rice residue incorporation with application of $30 \%$ additional $\mathrm{N}+\mathrm{P}+\mathrm{K}+$ recommended NPK and rice residue incorporation with application of $15 \%$ additional $\mathrm{N}+\mathrm{P}+\mathrm{K}+$ recommended NPK against sowing of wheat without incorporation of rice residue + recommended NPK. It is probably due to the fact that addition of carbonaceous substances in soil which on decomposition added organic matter. Moreover, residue retention on soil surface has also been shown to increase the amount of SOC concentration (Wilhelm et al., 2004). In a long term study (11 years) conducted by Dikgwatlhe et al., (2014) it was found that zero-tillage with residue retention resulted in an increase of SOC in the $0-10 \mathrm{~cm}$ soil layer compared to rotary tillage with residues incorporated and PT with residue retention and removed. Similar results were observed by Blanco- Canqui and Lal, (2008) in a CA study conducted over a period of 10 years. The rate of residue decomposition depends not only on the amount retained but also on the characteristics of the soil and the composition of the residues (Verhulst et al., 2010). In previous studies, higher soil organic 
C contents under zero till with residue return than under conventional tillage (Razafimbelo et al.,2008), under reduced tillage than under conventional tillage (Šimanský et al.,2008), have been reported. Lin et al., (2008) observed a very large $59-63 \%$ increase in SOC after incorporation of green manure in conjunction with industrial waste water. An overall relative increase in the SOC content was achieved under green manuring with Sesbania rostrata, Sesbania aculeate, and green gram residue over fallow in a rice field.

Chen et al., (2009) observed that shallow tillage (with residue retention) and ZT (with residue retention) treatments had 14.2 and $13.7 \%$ higher total SOC than CT (without residue retention) in the upper $15-\mathrm{cm}$ soil layer after $11 \mathrm{yr}$ of maize (Zea mays L.) mono-cropping in the Loess Plateau of China. Gershenson et al., (2009) reported that $\mathrm{T}_{3}$ (FYM treatment) and $\mathrm{T}_{5}$ (crop residue treatment) had lower activation energies of SOC decomposition among the organic treated plots indicating a lesser thermal sensitivity for macro-aggregate carbon. However a perusal of the $\mathrm{Q}_{10}$ values shows that SOC in macro-aggregates of $\mathrm{T}_{5}\left(\mathrm{Q}_{10}>2\right)$ is highly temperature responsive and the higher activation energy is due to chemical recalcitrance of the residues which is overcome with rises in temperature. Song et al., (2016) indicates that it is necessary to consider deeper soil when assessing the influence of tillage practices on soil organic carbon. Particularly in farmland under ricewheat rotation, different tillage practices combined with the alternating wet and dry soil environment cause quantitative changes in the soil organic carbon of deep soil. However, compared to zero tillage, conventional tillage, such as ploughing, incorporates organic materials, including straw mulch at the soil surface and residual roots in shallow soil, into deeper soil. The organic materials are tightly bound to soil particles, thereby improving the stability of their mineralization and promoting the accumulation of organic carbon in the deep soil Pinheiro et al., (2004).

Fig.1 A generalized summary of soil aggregates stabilization by various sources of organic matter Source: (Dalal and Bridge, 1996)

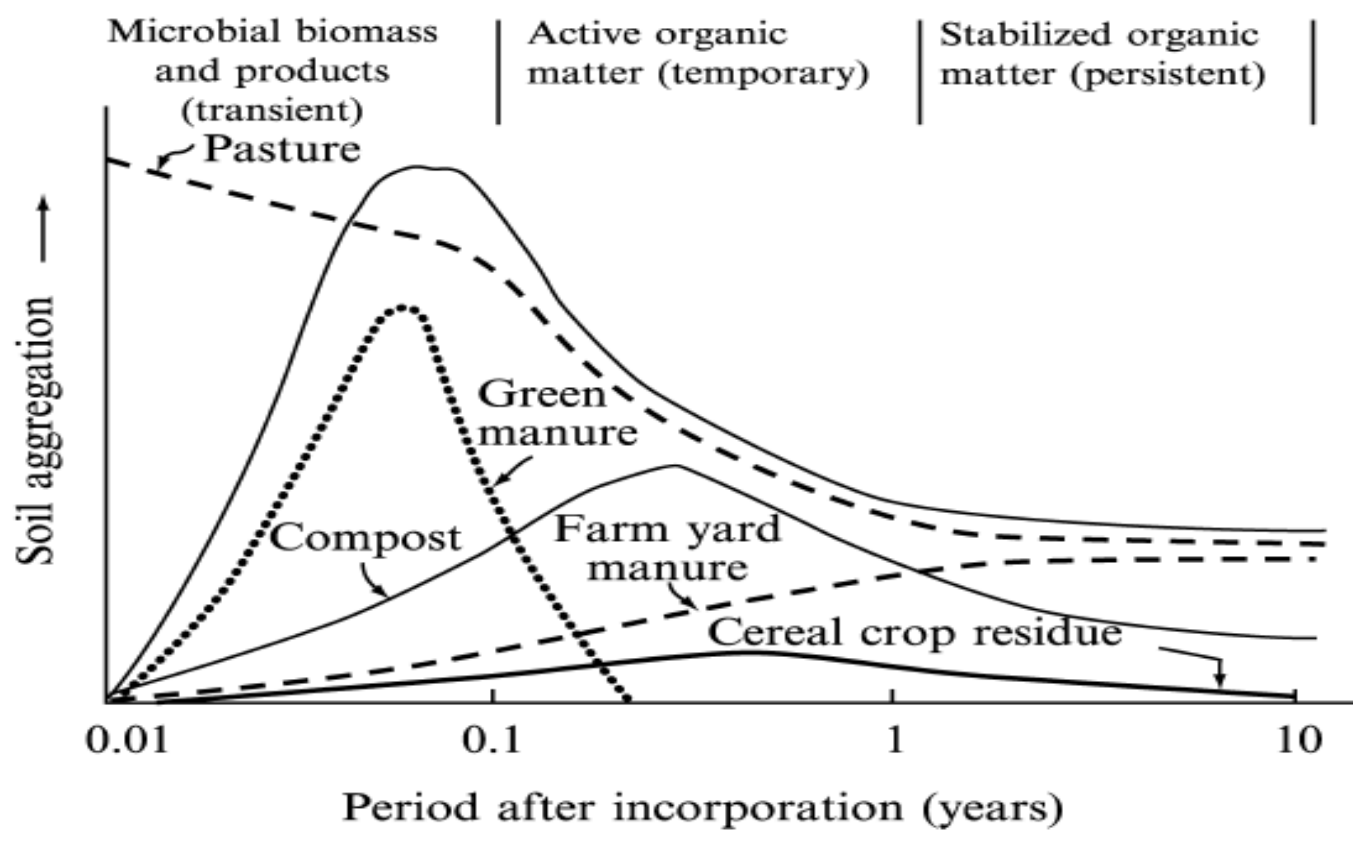


Fig.2a The multiplicity of interactions and feedbacks formation and stabilization described by Tisdall and Oades (1982) vs. postulated by Oades (1984). Fig.2b The opposing chronology of the formation between the five major factors influencing aggregate of the hierarchical aggregate orders implicitly
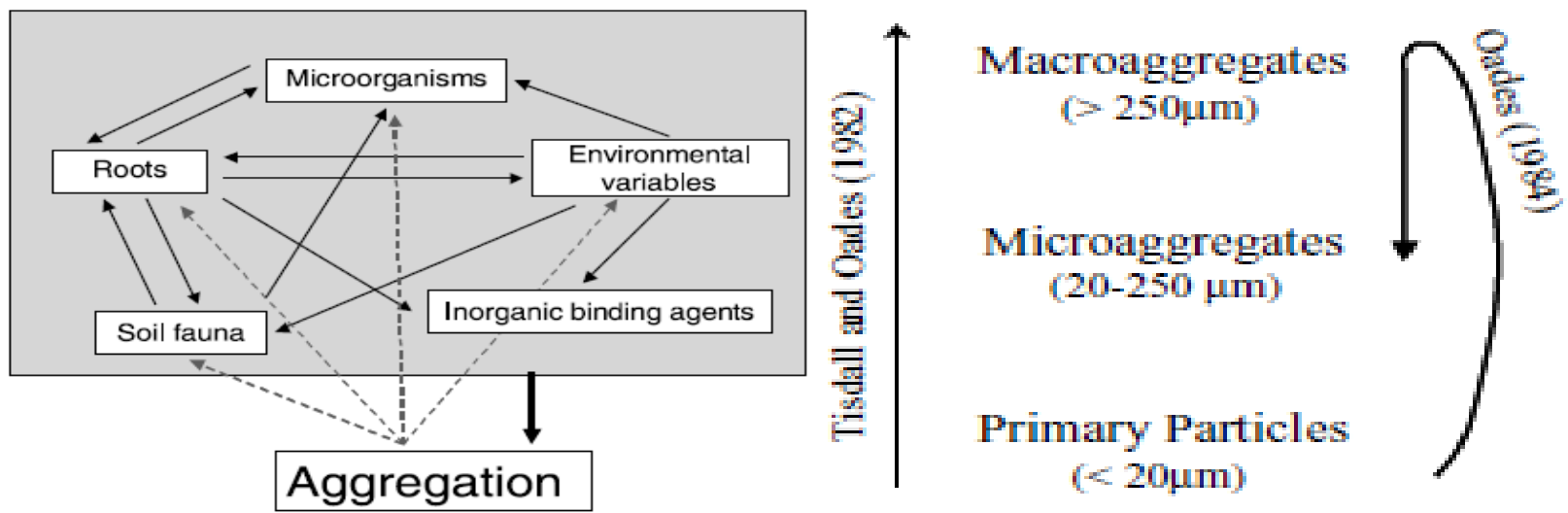

Fig.3 This conceptual model of the 'life cycle 'of a macro-aggregate shows the formation of new microaggregates within-macro-aggregates and the accumulation and mineralization of aggregate-associated organic C (Adapted from Six et al., 2000)

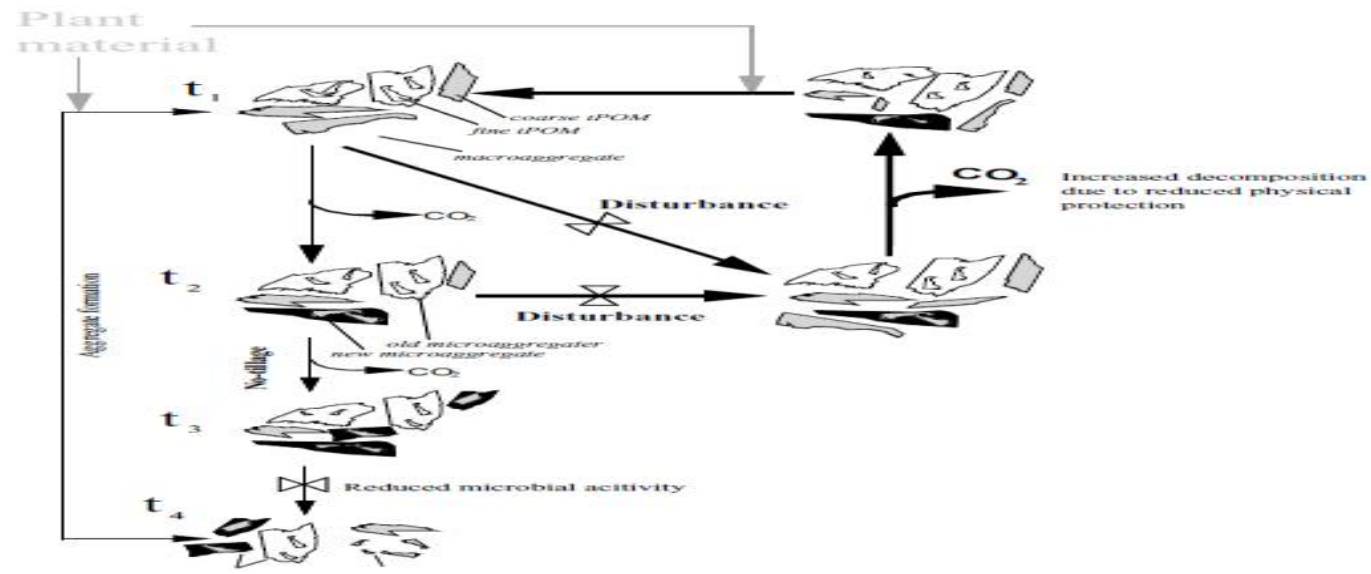

Fig.4 Change in aggregate turnover and mineralization of newly added $\mathrm{C}$ input across ecosystems representing a range of disturbance regimes. Figure based on Plante and McGill (2002a)

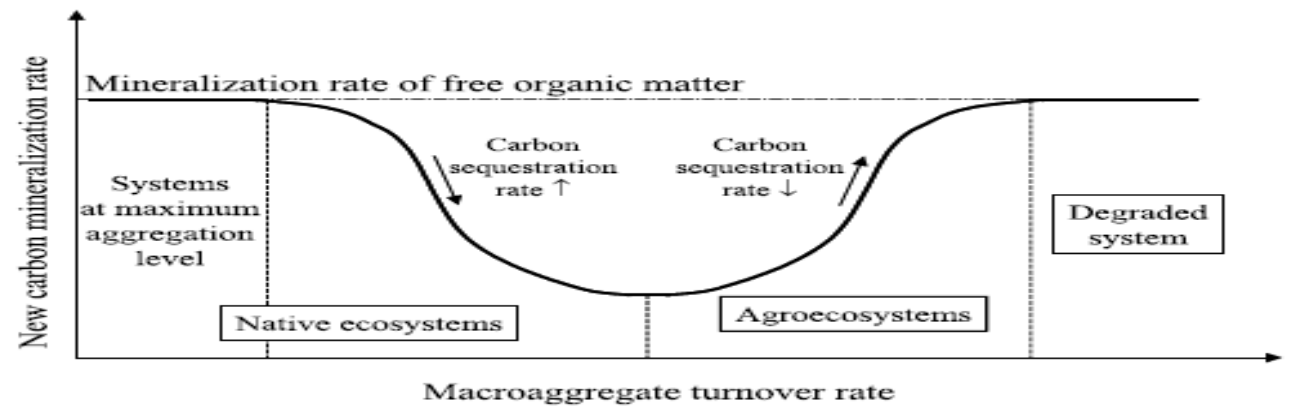


Fig.5 Relationship between the Henin instability index (Is) and infiltration rate (k). Adapted from Maymard and Combeau, 1960

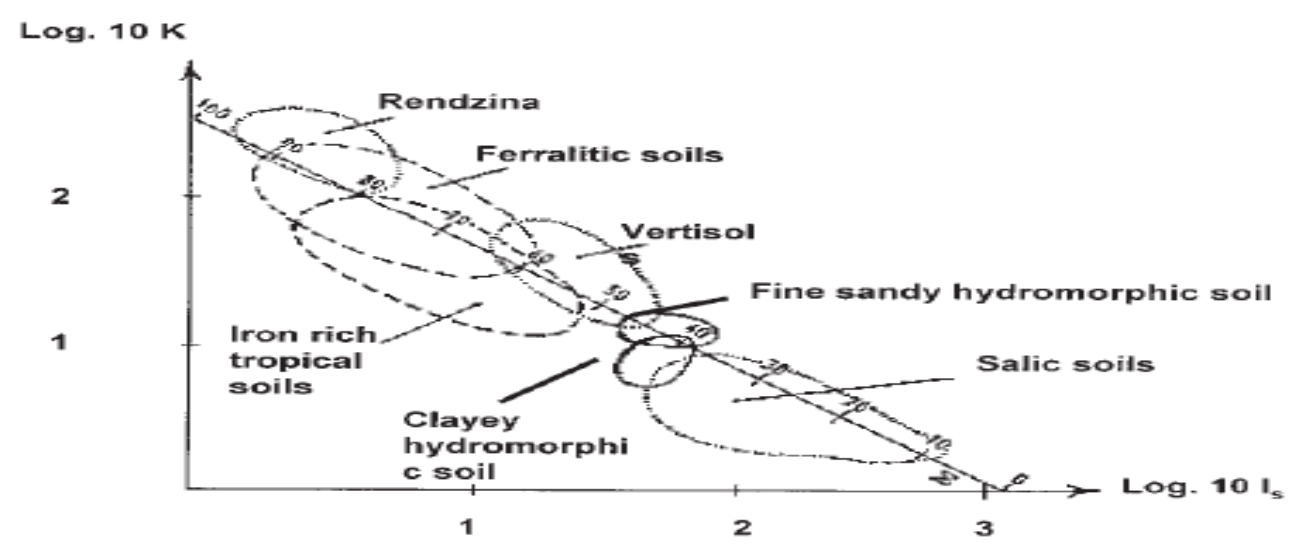

Fig.6 The C dynamics within different spheres of the earth as of 2013 (IPCC Climate report, 2013)

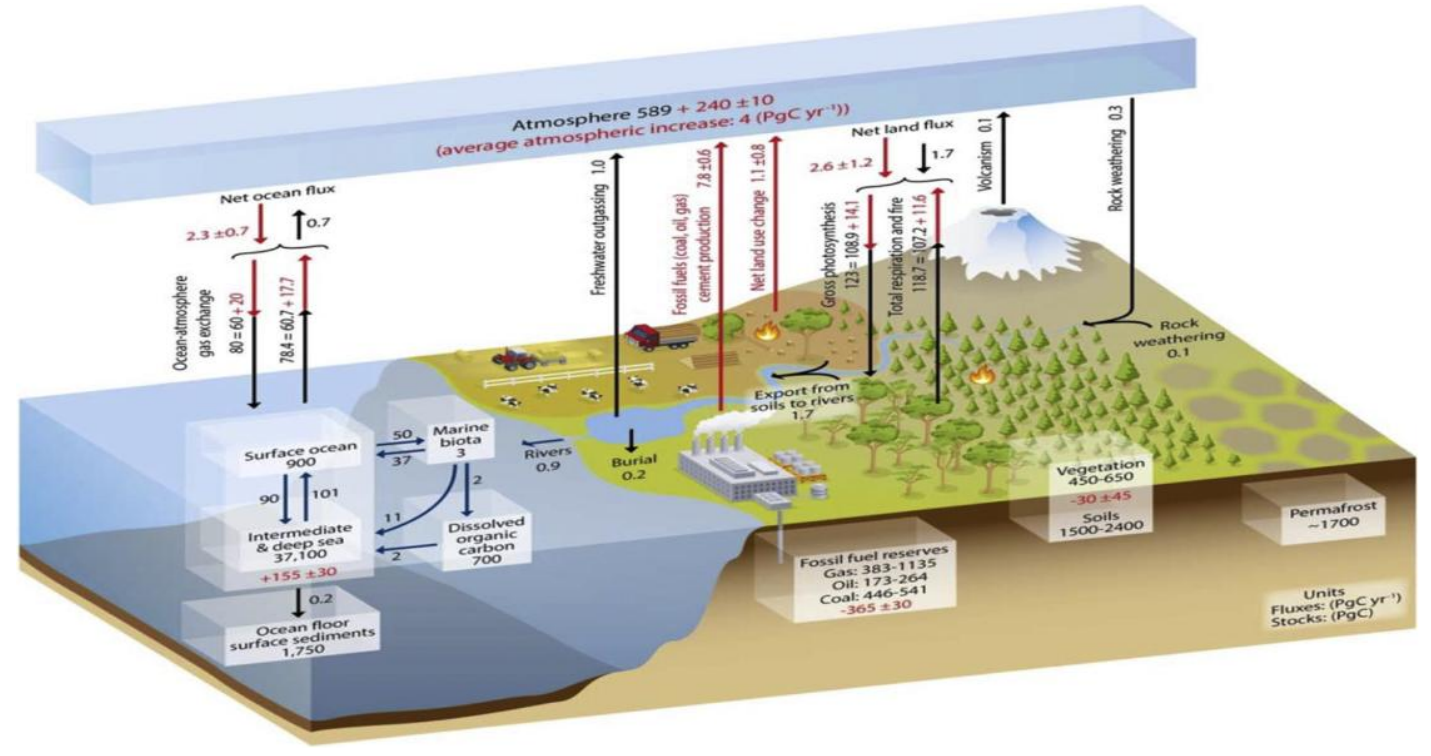

Fig.7 Scientist and farmers evaluate chopped and retained stubbles for their efficacy in soil carbon

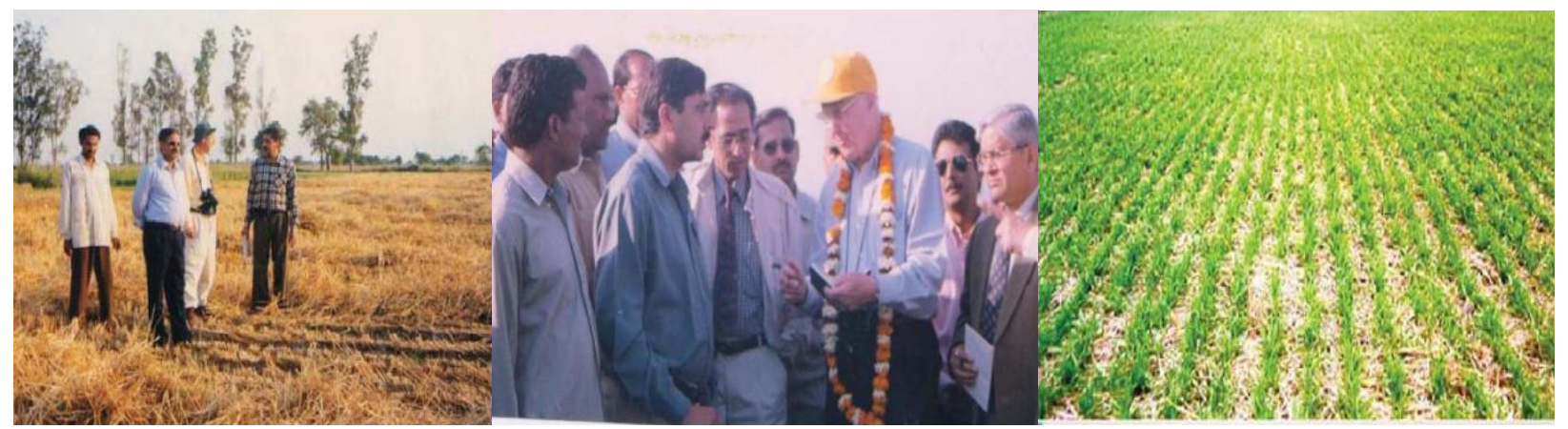



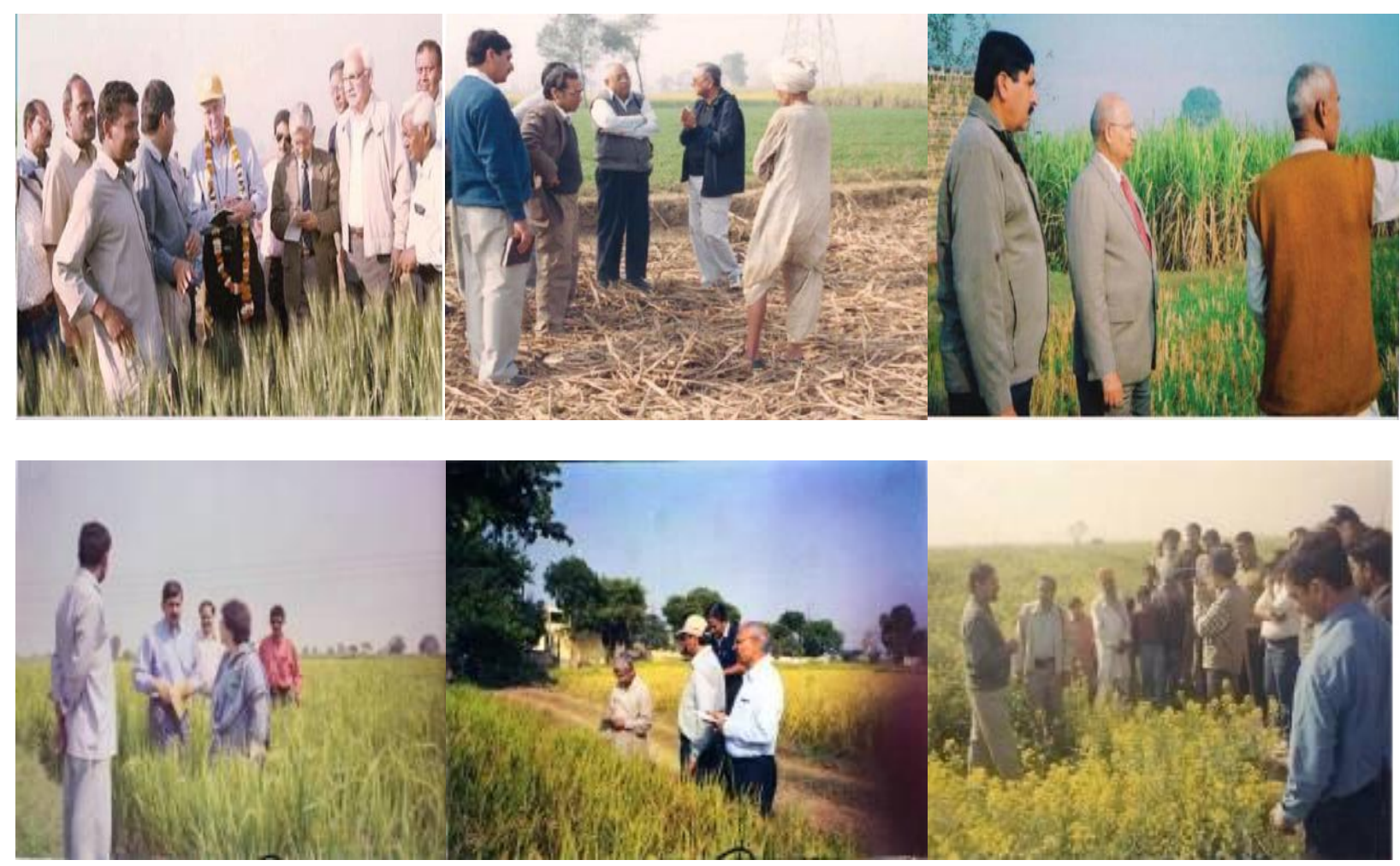

Fig.8 Aggregate formation and degradation mechanisms in temperate and tropical soils. Fungal and bacterial activity, active root growth and earthworm activity are the biological aggregate formation agents in both temperate and tropical soils, whereas the mineral-mineral interactions in tropical soils are the physicochemical aggregate formation agents

TEMPERATE and TROPICAL

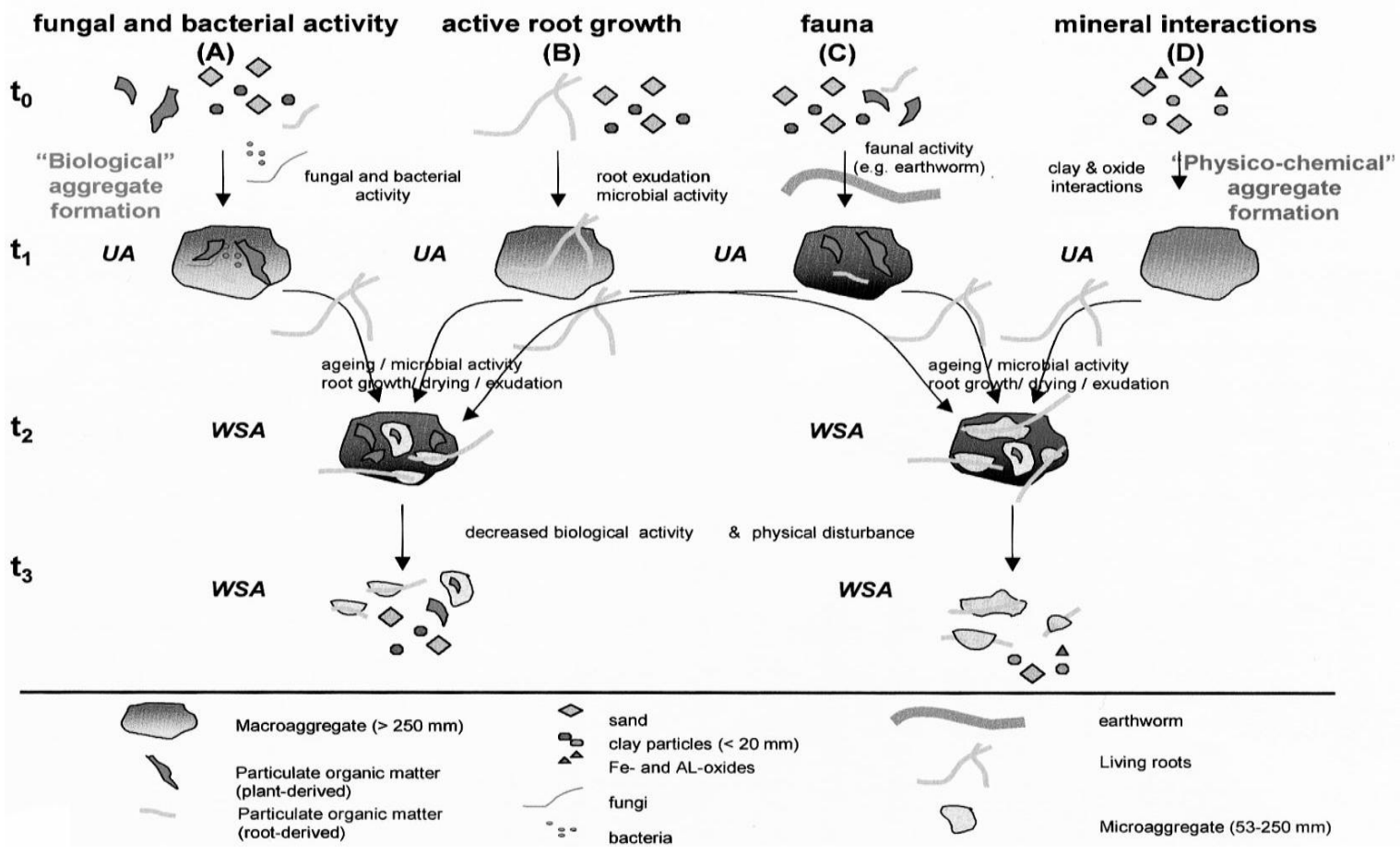


Table.1 Changes in soil physical and biological health indices in 100 year permanent trial in an Alfisol at Coimbatore

\begin{tabular}{|c|c|c|c|c|c|c|c|}
\hline \multirow[t]{3}{*}{ Treatment } & \multirow{3}{*}{$\begin{array}{l}\text { Soil Depth } \\
\quad(\mathbf{c m})\end{array}$} & \multicolumn{3}{|c|}{1983 (Rainfed) } & \multicolumn{3}{|c|}{2009 (Irrigated) } \\
\hline & & Bacteria & Fungi & Actinomycetes & Bacteria & Fungi & Actinomycetes \\
\hline & & $10^{6} / \mathrm{g}$ & $10^{4} / \mathrm{g}$ & $10^{4} / \mathrm{g}$ & $10^{6} / \mathrm{g}$ & $10^{4} / \mathrm{g}$ & $10^{4} / \mathrm{g}$ \\
\hline \multirow[t]{3}{*}{ Control } & $0-5$ & 19.2 & 7.2 & 2.3 & 34.9 & 8.1 & 8.9 \\
\hline & $5-15$ & 10.8 & 1.8 & 1.2 & 26.6 & 2.6 & 6.5 \\
\hline & $15-30$ & 8.7 & 0.5 & 1.1 & 20.0 & 1.9 & 4.3 \\
\hline \multirow[t]{3}{*}{ NPK } & $0-5$ & 22.3 & 14.2 & 7.7 & 83.5 & 31.8 & 16.5 \\
\hline & $5-15$ & 14.4 & 3.7 & 4.7 & 43.6 & 8.6 & 14.4 \\
\hline & $15-30$ & 9.4 & 1.3 & 1.9 & 15.9 & 3.9 & 9.5 \\
\hline \multirow{3}{*}{$\begin{array}{l}\text { Cattle } \\
\text { manure }\end{array}$} & $0-5$ & 26.8 & 10.3 & 9.5 & 103.0 & 39.6 & 20.4 \\
\hline & $5-15$ & 16.2 & 6.0 & 6.8 & 90.6 & 17.5 & 11.2 \\
\hline & $15-30$ & 13.7 & 2.9 & 4.0 & 68.9 & 4.6 & 8.1 \\
\hline
\end{tabular}

* Source: Boopathi et al., (2011)

Table.2 Changes in bacterial and fungal numbers and soil microbial biomass 21 weeks after the growth of inoculated BGA in surface one $\mathrm{cm}$ of a brown earth soil in UK

\begin{tabular}{|c|c|c|}
\hline Property & Dark Control & Inoculated Cyanobacteria \\
\hline Bacteria $\left(\times 10^{7}\right)$ & 17.5 & 48.4 \\
\hline Fungi $\left(\mathrm{x} \mathrm{10} 0^{4}\right)$ & 1.7 & 2.7 \\
\hline $\operatorname{SMBC}^{\mathrm{a}}\left(\mathrm{mg} \mathrm{C} 100 \mathrm{~g}^{-1}\right)$ & 59.2 & 118.6 \\
\hline Dehydrogenase $^{\mathrm{b}}$ & 50.9 & 107.5 \\
\hline Urease $^{\mathrm{c}}$ & 1.31 & 3.61 \\
\hline Phosphatase $^{\mathrm{d}}$ & 0.44 & 1.40 \\
\hline Polysaccharides $^{\mathrm{e}}$ & 3.94 & 6.67 \\
\hline Stability index ${ }^{f}$ & 0.787 & 0.818 \\
\hline
\end{tabular}

${ }^{a} \mathrm{mg} \mathrm{C} 100 \mathrm{~g}^{-1}$ soil; ${ }^{b} \mu \mathrm{g} \mathrm{TPF} \mathrm{g}^{-1}$ soil in $24 \mathrm{~h}^{\circ}{ }^{c} \mu \mathrm{mol} \mathrm{NH} \mathrm{g}^{-1}$ soil $\mathrm{h}^{-1} ;{ }^{d} \mu \mathrm{g} P N P \mathrm{~g}^{-1} \mathrm{~h}^{-1},{ }^{e} \mathrm{mg}$ glucose $\mathrm{g}^{-1},{ }_{\text {indirect }}$ measure of POM.

Source: Rao and Burns (1990).

Table.3 Organic carbon and biological activity under different tillage practices at the end of four cropping cycles in North-east India

\begin{tabular}{|l|c|c|c|c|}
\hline \multicolumn{1}{|c|}{ Treatment } & $\begin{array}{c}\text { Organic carbon } \\
(\boldsymbol{\%})\end{array}$ & $\begin{array}{c}\text { SMBC } \\
(\boldsymbol{\mu g} / \mathbf{g} \text { soil })\end{array}$ & $\begin{array}{c}\text { Earthworm } \\
\text { population }\end{array}$ & $\begin{array}{c}\text { Dehydrogenase activity } \\
(\boldsymbol{\mu g} \text { TPF/g/24 h) }\end{array}$ \\
\hline Conventional tillage & 1.47 & 91.3 & 60,000 & 29.5 \\
\hline Zero tillage & 2.23 & 128.5 & $1,60,000$ & 131.5 \\
\hline Double no-till & 2.51 & 134.1 & $3,80,000$ & 166.6 \\
\hline Minimum tillage & 2.17 & 121.3 & $1,00,000$ & 127.5 \\
\hline $\mathrm{CD}(\mathrm{P}=0.05)$ & 0.78 & 12.1 & - & 27.5 \\
\hline
\end{tabular}

$O C$, organic carbon; $S M B C$, Soil microbial biomass carbon

Source: Ghosh et al., (2010).

Table.4 Effect of fertilizers on soil biological properties in a pearl millet-wheat rotation in a sandy loam at Hisar.

\begin{tabular}{|c|c|c|c|c|c|c|}
\hline Treatment & $\%$ Org C & $\% \mathrm{~N}$ & SMBC & SMBN & Bacteria, $10^{6} / \mathrm{g}$ & DHA \\
\hline $\mathbf{N}_{0} \mathbf{P}_{0} \mathbf{K}_{0}$ & 0.42 & 046 & 150 & 18 & 7 & 53 \\
\hline $\mathbf{N}_{60} \mathbf{P}_{30} K_{60}$ & 0.40 & 0.059 & 270 & 51 & 48 & 87 \\
\hline $\mathbf{N}_{120} \mathbf{P}_{60} \mathbf{K}_{60}$ & 0.49 & 0.062 & 368 & 68 & 63 & 75 \\
\hline LSD $p=0.05$ & 0.02 & 0.003 & 42 & 13 & 16 & 9 \\
\hline
\end{tabular}

*SMBC, SMBN= $\mathrm{mg} \mathrm{kg}^{-1}$ soil, Dehydrogenase, DHA $=\mu \mathrm{g}$ triphenyl formazon $\mathrm{g}^{-1}$ soil $24 \mathrm{~h}^{-1}$,

Source: Goyal et al., (1992). 
Naresh et al., (2017) revealed that the average SOC concentration of the control treatment was $0.54 \%$, which increased to $0.65 \%$ in the RDF treatment and $0.82 \%$ in the RDF+FYM treatment and increased enzyme activities, which potentially influence soil nutrients dynamics under field condition. Compared to $\mathrm{F}_{1}$ control treatment the RDF+FYM treatment sequestered $0.28 \mathrm{Mg} \mathrm{C}^{-1} \mathrm{yr}^{-1}$ whereas the NPK treatment sequestered $0.13 \mathrm{Mg} \mathrm{C}^{-1} \mathrm{yr}^{-}$ 1 . As tillage intensity increased there was a redistribution of SOC in the profile, but it occurred only between ZT and PRB since under CT, SOC stock decreased even below the plow layer. Increased SOC stock in the surface $50 \mathrm{~kg} \mathrm{~m}^{-2}$ under ZT and PRB was compensated by greater SOC stocks in the 50200 and $200-400 \mathrm{~kg} \mathrm{~m}^{-2}$ interval under residue retained, but SOC stocks under CT were consistently lower in the surface $400 \mathrm{~kg} \mathrm{~m}^{-2}$. Over the last 16 years, CT lost $0.83 \pm 0.2 \mathrm{~kg}$ of $\mathrm{C} \mathrm{m}^{-2}$ while ZT gain $1.98 \pm 0.3$ and $\mathrm{PRB}$ gain $0.97 \pm 0.2 \mathrm{~kg}$ of $\mathrm{C} \mathrm{m}^{-2}$ in the $1200 \mathrm{~kg}$ of soil $\mathrm{m}^{-2}$ profile. These findings suggest that carbon sequestration can be improved if treatments $\mathrm{T}_{4}$ or $\mathrm{T}_{6}$ are used in lieu of $\mathrm{T}_{7}$, respectively

\section{Organic agriculture and carbon sequestration}

Feng and $\mathrm{Li}$ (2001) concluded that for the same carbon input, carbon storage in soil was higher by $1.18 \mathrm{t} \mathrm{ha}^{-1} \mathrm{C}$ with manure application than with plant residues. Whalen and Chang (2002) reported that manure application promoted the formation and stabilization of soil macro aggregates. Liu et al., (2005) found that the profile average SOC content $(0-90 \mathrm{~cm})$ was only $0.9 \%, 4.1 \%$, and $8.6 \%$ higher for manure, chemical fertilizers, and manure plus fertilizers, respectively, than that with no fertilizer application or control in the Chinese Mollisols. However, SOC at the 0- $15 \mathrm{~cm}$ soil layer was $6.2 \%, 7.7 \%$, and $9.3 \%$ higher with manure, chemical fertilizers, and manure plus fertilizers, respectively, than with no fertilizer application. These results indicated that the annual rate of decline rate of SOC in the $015 \mathrm{~cm}$ layer without fertilizer was not very high $(<0.58 \% / y r)$ when a welldesigned crop rotation was used (Table 3 ).

Kukal et al., (2009) revealed that application of FYM and inorganic fertilizer in rice-wheat and maize-wheat cropping systems. They reported that the SOC sequestration rate was higher in FYM plots in comparison to NPK plots in both the cropping systems. Also the sequestration rate was three times higher in rice-wheat than in maize-wheat cropping system. Parker et al., (2002) who obtained 7$20 \%$ higher organic carbon in top soil layer (5 $\mathrm{cm}$ ) in cotton-rye cropping system with poultry litter as compared to fertilizer. In organic agriculture, biomass is not burned. It reduces the $\mathrm{N}_{2} \mathrm{O}$ emissions by $0.6-0.7 \mathrm{Gt}^{-\mathrm{CO}_{2}}$ e $\mathrm{yr}^{-1}$ in comparison to conventional agriculture (Smith et al., 2007). Organic systems are highly adaptive to climate change due to: (a) the application of traditional skills and farmers' knowledge, (b) soil fertilitybuilding techniques, and (c) a high degree of diversity. Liu et al., (2013) revealed that the average concentration of particulate organic carbon (POC), dissolved organic carbon (DOC) and microbial biomass carbon (MBC) in organic manure plus inorganic fertilizer treatments $(\mathrm{NP}+\mathrm{S}$ and $\mathrm{NP}+\mathrm{FYM})$ in $0-60 \mathrm{~cm}$ depth were increased by 64.9-91.9\%, 42.5$56.9 \%$, and $74.7-99.4 \%$, respectively, over the CK treatment. Niggli et al., (2009) found that an organic approach 40 per cent of the GHG emissions of agriculture could be mitigated by sequestering carbon into soils at rates of $100 \mathrm{~kg}$ of $\mathrm{C} \mathrm{ha}^{-1} \mathrm{yr}^{-1}$ for pasture land and $200 \mathrm{~kg}$ of $\mathrm{C} \mathrm{ha}^{-1} \mathrm{yr}^{-1}$ for arable crops. By combining organic farming with reduced tillage, the sequestration rate can be increased to $500 \mathrm{~kg}$ of $\mathrm{C} \mathrm{ha}^{-1} \mathrm{yr}^{-1}$ in arable crops as compared to ploughed conventional cropping systems, but as the soil $\mathrm{C}$ dynamics reach a new equilibrium, these rates will decline in 
the future. This would reduce GHG emissions by another 20 per cent. Organic farming is an important option in a multifunctional approach to climate change. Application of $50 \% \mathrm{~N}$ through different organics (FYM, green manure or wheat cut straw) plus $50 \%$ NPK through chemical fertilizers were better over other treatments in respect of soil organic carbon of soil (Sepehya et al., 2012). Bhattacharyya et al., (2008) have advocated the usage of organic inputs toward achieving better soil quality with elevated SOC content, enhanced agronomic stability, and improved soil structure. Abd El-Fattah et al., (2013) also found that different types of amendments (compost, green manure, bio-fertilizer, and raw wastes) on plant soil systems not only showed very similar patterns, but were also identified as very dependent on considerable variabilities (e.g., agricultural techniques, climate, soil type and texture, and material characteristics). Among the numerous changes associated with soil properties, biochemical and microbiological properties have been identified as very sensitive to additional organic inputs by soil modification (Table 4).

Beesley et al., (2014) opined that incorporation of organic manure to the soil should substitute for lost $\mathrm{C}$ which in turn should modulate the dynamics of soil $\mathrm{C}$ pools. Apart from the addition of essential nutrients to the soil, organic inputs also eradicate the problems of heavy metal pollution to a considerable degree. Naresh et al., (2017) revealed that the carbon $(\mathrm{C})$ sequestration is a cost-effective strategy to mitigate climate change during the first few decades of the $21^{\text {st }}$ century. There are five global $\mathrm{C}$ pools, and the third largest pool exists in soil and is estimated at 2.5 trillion tons (1-m depth). The conversion of natural ecosystems to agricultural ecosystems disturbs the soil ecological balance, soil processes, organic $\mathrm{C}$, and biotic $\mathrm{C}$ pools.

\section{Microbial population and activity}

Residue incorporation into the soil leads to increased bacterial and fungal activities (Beare et al., 1996; Doran, 1980). For example, protein decomposing microorganisms increased during the early stages of incubation of rice straw under waterlogged conditions (Fujii et al., 1972), which was followed by an increase in the population of cellulose-decomposing microorganisms. Sulphate-reducing microorganisms then increased after a lag phase. Nugroho and Kawatskka (1992a) observed that application of rice straw $(\mathrm{C}: \mathrm{N}$ $=52: 1)$ increased all the microbial populations.

In that study, simultaneous application of rice straw and $\mathrm{NH}_{4}^{+}-\mathrm{N}$ to soil under upland conditions increased the number of denitrifiers but significantly depressed the N2 fixation activity. Beri et al., (1992) also observed that soil treated with crop residues inhabited 5-10 times more aerobic bacteria and 1.5-11 times more fungi than the soil for which residues were either burned or removed. Fujii et al., (1970), in contrast, found that with a short-term incubation period (10 or 20 days) in an aerobic soil, the population of nitrifying bacteria was higher in the absence of rice straw, but the reverse was true with longer incubation periods (60 or 90 days). Ladatko and Emtsev (1984) observed marked increase in the growth of Clostridium spp. in a soil amended with rice straw. The increase in the growth of anaerobic microorganisms was due to the formation of artificial anaerobic micro-sites around the straw particles. Last but not least, residue quality may affect the microbial population, as smaller bacterial and fungal populations are greater on cereal residues compared to those on legumes. As compared to bacteria, fungi are more influenced by residue quality (Wardle, 1995). 
Six et al., (1999) indicated that in addition to the amount of aggregation, the rate of turnover of soil aggregates influences $\mathrm{C}$ stabilization. Microbial growth and the resulting production of extracellular polysaccharides bind residue and soil particles into macro-aggregates. Following the incorporation of fresh plant material, microorganisms utilize the more easily decomposable carbohydrates, yielding intraaggregate POM (iPOM). Wang and Bakken (1997b) reported that the depressing effect of plant uptake of $\mathrm{N}$ on soil microbial biomass was much pronounced in $\mathrm{N}$ poor barley straw layer suggesting that microbial growth in soil can be limited by nutrient supply rather than $\mathrm{C}$ availability. In our study, half early/half late $\mathrm{N}$ treatment had higher $\mathrm{C}$ substrate with lower available $\mathrm{N}$ concentration than the full $\mathrm{N}$ treatments. Spedding et al., (2004) found that residue management had more influence than tillage system on microbial characteristics, and higher SMB-C and N levels were found in plots with residue retention than with residue removal, although the differences were significant only in the $0-10 \mathrm{~cm}$ layer. Wuest et al., (2005) observed that Residue retention can have a varying effect on earthworms, however, depending on their ecological niche, as tillage may benefit endogeic (horizontal-burrowing) earthworms if residue is incorporated into the soil, providing a food source.

The effect of crop residue on earthworms and other soil fauna can thus vary depending on tillage frequency, plow depth, residue incorporation, and crop residue type, amount and quality (Eriksen-Hamel et al., 2009).

Based on Six et al., (200b), Jastrow (1996), Kemper Rosenau (1986), Wander and Yang (2000).

$\mathrm{UA}=$ unstable aggregates; WSA = waterstable aggregates.
Ha et al., (2008) reported that different residues resulted in different levels of POM, which cultivate distinct microbial communities. James et al., 2010 revealed that long-term no-tilled soils have significantly greater levels of microbes, more active carbon, more SOM, and more stored carbon than conventional tilled soils. A majority of the microbes in the soil exist under starvation conditions and thus they tend to be in a dormant state, especially in tilled soils. Wang et al., (2012) reported increased microbial biomass carbon with crop residue application in comparison to no crop residue application. Moharana et al., (2012) revealed that the highest values of TOC $\left(11.48 \mathrm{~g} \mathrm{~kg}^{-1}\right)$ and WBC $\left(7.86 \mathrm{~g} \mathrm{~kg}^{-1}\right)$ were maintained in FYM treated plot, while the highest values of LBC (1.36 $\left.\mathrm{g} \mathrm{kg}^{-1}\right)$ and MBC (273 $\left.\mathrm{mg} \mathrm{kg}^{-1}\right)$ were found in FYM + NPK. The magnitude of change in pools of SOC in sub-surface (15-30 $\mathrm{cm})$ soil was low as compared to the surface soil $(0-15 \mathrm{~cm})$. Significant increase in all the pools of SOC in FYM treated plots indicates the importance of application of organic manure like FYM in maintaining organic carbon in soil.

Naresh et al., 2016 showed that in 3-year experiment LFON content in $0-5 \mathrm{~cm}$ soil layer of CT system, $\mathrm{T}_{1}$, and $\mathrm{T}_{5}$ treatments increased LFOC content from $5.1 \mathrm{mg} \cdot \mathrm{kg}^{-1}$ in CT $\left(\mathrm{T}_{9}\right)$ to 7.9 and $9.6 \mathrm{mg} \cdot \mathrm{kg}^{-1}$ without $\mathrm{CR}$, and to $10.3,11.5$ and $13.1 \mathrm{mg} \cdot \mathrm{kg}^{-1}$ with crop residue @ 2, 4 and 6 tha $^{-1}$, respectively. Compared to conventional tillage (CT), notillage and reduced tillage could significantly improve the SOC content in cropland. The enhanced microbial activity induces the binding of residue and soil particles into macro-aggregates, which could increase aggregates stability thus improving the concentration of SOC and increasing $\mathrm{C}$ sequestration (Liqun et al., 2014). Carbon input in the form of crop residue had primary factor for stabilization of soil carbon (Singh, 
2011). The microbial activity was found more on residue retained plots (Mandal et al., 2004) so that soil organic carbon level increased with the residue retention (Duiker and Lal, 1999). Berger et al., (2013) enumerated the effectiveness of a mixed biofertilizer (phosphate and potash rocks + earthworm compound + free living diazotrophic bacteria and Cunninghamella elegans) on increased nodulation and yield in cowpea.

\section{Macroorganisms}

Earthworms and micro-arthropods play a dominant role in organic matter decomposition and nutrient cycling associated with different crop residue management systems (Prasad and Power, 1991; Tian et al., 1993). Although enough information is not available from rice-based cropping systems, residue quality greatly influences macroorganism populations in the soil. For example, the earthworm population was negatively correlated with the $\mathrm{C}$ : $\mathrm{N}$ ratio, lignin: $\mathrm{N}$ ratio, and polyphenol concentration of the plant material (Tian et al., 1992), and the population of ants were significantly correlated to $\mathrm{N}$ concentration of plant residues (Tian et al., 1993). Nayak et al., (2007) has been shown that although organically farmed soils had greater microbial abundance and activity, as also higher number of bacterialfeeding nematodes than those managed under conventional farming practices, the ability of microbial communities per se in the two soils (chemically or organically fertilized) to degrade added organic matter did not differ. Wuest (2014), Lou et al., (2012), Sun et al., (2010) also explained the slight differences in the SOC and TN concentrations in the whole profile between the two years can be attributed to the difference in the activities of soil microorganisms and the rate of residue decomposition due to the seasonal variation in soil temperature and moisture regimes. The results presented herein indicate that soils with retained rice residue had higher SOC and TN concentrations at all soil depths than that with the rice residue removed in both years.

(Boopathi et al., 2011) reported that the results of the permanent manurial trial started in 1909 at Coimbatore show that NPK and cattle manure (CM) applied (12.5 t/ha) were mostly at par. SOC change during 2003-08 was $+0.18 \%$ in NPK fertilized and $+0.19 \%$ in manure treated plots (Table 1). The CM treatment did not show much improvement in soil aggregation over NPK. Microbial population under rained conditions (measured in 1983) was similar while in irrigated condition (in 2009) CM-treated plots had higher microbial population over NPK plots. Rao and Burns, (1990) observed that inoculation with BGA in submerged soils improves the general health of soils through building up organic matter, stimulating the bacterial and fungal populations, microbial biomass, soil enzyme activities, polysaccharide production and soil aggregation (Table 2). Wang et al., (2012) also found that the mycorrhizae biomarkers were significantly enriched under no-till treatments, which has also been observed for other cropping systems like rotated maize and wheat. This study was able to establish linkages between shifts in the microbial community structure due to no-tillage that were associated with greater activities of key enzymes of $\mathrm{C}$ and $\mathrm{N}$ (b-glucosidase), N (bglucosaminidase) and $\mathrm{P}$ cycling (phosphodiesterase) relative to till. The shift in microbial community structure, and increased enzyme activity found under no-till for this soil under cotton production provides evidence that it can take several years of surface residue accumulation for this particular crop. Gunapala et al., (1998) found that the ability of soil microorganisms to decompose added organic matter was the same in organic or conventional systems and that microbial diversity was not compromised 
by chemical farming with the conclusion that integrated systems are the best. Waring et al., (2013) revealed that reduced tillage is expected to increase the ratio of fungal to bacterial (F: B)-FAME biomarkers. Besides minimal disruption of their hyphal networks, the abundance of fungi has been hypothesized to be greater under reduced tillage mainly because of their cell structural composition comprised of chitin that is more resistant to degradation and has been linked with greater soil $\mathrm{C}$ sequestration.

\section{Enzyme activities}

Barreto and Westerman (1989) and Gill et al., (1998b) observed a significant increase in urease activity in surface soils after incorporation of wheat straw. Likewise, Guan (1989) reported that application of wheat straw increased the invertase activity of soil by 40-90 times compared to the control treatment in both laboratory and field experiments and that the activities of urease and alkaline phosphatase were also increased by wheat straw additions. Gialhe et al., (1976) observed that dehydrogenase activity increased with rice and wheat straw incorporation and was further increased by $\mathrm{N}$ application. Goyal and Chander (1998) also reported an increase in the microbial biomass and dehydrogenase and alkaline phosphates activities with the addition of wheat straw to a sandy loam soil. Rao, (2007) found that the soil microbial biomass was highest under rice-clover, lowest under rice-mustard and intermediate in rice-wheat and sorghumwheat systems. Metabolic quotient, $\mathrm{qCO}_{2}$ was higher in rice-clover and rice-mustard as compared to rice-wheat with sorghum-wheat being the lowest. Higher organic carbon, respiration and dehydrogenase activity reflects the influence of more readily available carbonaceous substrates and a greater 'zymogenous' microbial population.

Rupela et al., (2005) reported that in an experiment on low-input farming at the ICRISAT Center, near Hyderabad, no- tillage along with addition of rice straw mulch or farm waste mulch (microbial inoculants and bio-pesticides were applied in both) was compared with conventional tillage system with (i) NP fertilizers plus chemical pesticides and (ii) an integrated system involving chemicals and biomass mulch. After 5 years, SOM content, microbial biomass and soil respiration were higher in the two organic plots (with no-till and biomass mulch) as compared to conventional, chemical farming with normal tillage, but highest in the integrated (chemical + plant biomass residue) treatment with normal tillage. In a 2-year field experiment on a sandy loam soil in north India on wheat, conservation tillage significantly increased soil respiration $(+81.1 \%), \quad$ SBMC $(+104 \%)$ and soil dehydrogenase activity $(+59.2 \%)$ compared to conventional tillage (Sharma et al., 2011). Similarly, in a field study on four tillage practices in $\mathrm{NE}$ India on ricewheat/mustard/linseed, zero tillage (residue retention and double no-till) recorded higher SMBC, dehydrogenase activity and earthworm population which in turn resulted in good growth and higher yield of all the crops (Ghosh et al., 2010).

Sa et al., (2001) revealed that intensive tillage leads to substantial losses of soil carbon, (30 to $50 \%$ ). Cultivation depresses activity of soil enzymes. In contrast, conservation tillage causes less soil disturbance and has higher levels of enzymes in the surface soil. Raverkar et al., (2005) studies at a sandy soil site in Rajasthan, we found consistently higher populations of copiotrophic bacteria (that consume high amount of substrate and have higher growth rates) and oligotrophic bacteria ((bacteria that thrive on very low amount of substrate and have slow growth rates) actinomycetes, glomalin, biological activity (dehydrogenase, FDA hydrolysis) and 
activity of soil enzymes (acid phosphatase, Bglucosidase) in organic cropping and orchards compared to conventional cropping. on a sandy loam soil in north India on wheat, conservation tillage significantly increased soil respiration $(+81.1 \%)$, SBMC $(+104 \%)$ and soil dehydrogenase activity $(+59.2 \%)$ compared to conventional tillage (Sharma et al., 2011).

Acosta-Martínez et al., (2011) reported that an increase in enzyme activities and soil $\mathrm{C}$ and $\mathrm{N}$ storage under $\mathrm{CA}$ practices, particularly under no-till and vetch cover crop that translated in significantly greater TOC and b-glucosidase quality scores. These results highlight the importance of combining reduced tillage with $\mathrm{N}$-fixing cover crops in improving soil quality as well as yield even under low biomass monoculture production system in the long term.

Green et al., (2007) found that No-till management practice increase stratification of soil enzyme activities near the soil surface, perhaps due to the similar vertical distribution of SOM in NT than in CT and the activity of microbes. Lu et al., (2014) recently concluded that biochar and residue amendment could enhance the readily oxidized $\mathrm{C}$ (measured by $\mathrm{KMnO}_{4}$ oxidation). Zhang et al., (2013a) found that RDN+FYM application resulted in more nitrate in the upper $1 \mathrm{~m}$ of soil profile. Further study about residue and RDN+FYMinduced changes in soil biota (i.e., enzyme, microbial community) regarding soil $\mathrm{N}$ transformation (nitrification, denitrification) is needed, because the activity of enzymes involved in the $\mathrm{N}$ cycle could potentially be linked to $\mathrm{N}_{2} \mathrm{O}$ emissions ( $\mathrm{Wu}$ et al., 2013; Harter et al., 2013). Srinivasan et al., (2012) observed that SOC protection by soil aggregates, the newly added carbon provides physical protection and is then subjected to chemical conversion and structural stabilization; meanwhile, alternation of the properties and distribution of the carbon pool leads to both the diversification of aggregatescale microbial habitats and the evolution of microbial biota, along with changes in various fertility service functions such as functional groups and enzyme activity, which promote the development of diverse biota and thereby stabilize ecosystem processes.

Naresh et al., (2017) found that the ZT and PRB with 4 and 6 tha $^{-1}$ residue retention increased the number of nitrifying bacteria at the milky stage by $38.7,53.7$ and $72.4 \%$ as compared to CT (conventional tillage), respectively. Compared to the ZT method, the PRB method reduced the number of denitrifying bacteria by $49.6,14.9$, and $13.8 \%$ under $\mathrm{T}_{4}, \mathrm{~T}_{5}$, and $\mathrm{T}_{6}$ at the jointing stage but did not significantly decrease it at the booting stage. However, the ZT method increased the number of denitrifying bacteria at the milky stage by $9.4,15.7$ and $19.7 \%$ under $\mathrm{T}_{4}, \mathrm{~T}_{5}$, and $\mathrm{T}_{6}$ methods.

This long-term assessment was able to provide an overview of the effects of organic inputs on strength and stability of soil aggregates associated organic carbon concentration and the possible resultant effect on nutrient cycling under monoculture ricewheat system production. The results demonstrate the value of incorporating or retention of residues as a source of substrate for increased microbial activity resulting in greater soil $\mathrm{C}$ and $\mathrm{N}$ storage. It is apparent that after a continuous period of growing a rice-wheat monoculture crop with residue retention /incorporation, microbial activities that promote both $\mathrm{C}$ and $\mathrm{N}$ cycling are enhanced. Moreover the organic inputs/residue retention crop improves soil quality without the need of additional inorganic $\mathrm{N}$ fertilization. While the zero-till also affected soil $\mathrm{pH}$ which was significantly higher without organic input plots than other treatments. However, the trends observed 
with SOC indicated that conservation tillage managements were creating a more favorable plant growth environment relative to conventional tillage. The SOC concentration and its sequestration were higher with the treatment applied with organics than $\mathrm{N}-\mathrm{P}-\mathrm{K}$ application. Soil carbon sequestration with response to application of fertilizer substituted (50\% with organics were higher lying in semiarid climate.

Application of recommended dose of $\mathrm{N}-\mathrm{P}-\mathrm{K}$ or $\mathrm{N}-\mathrm{P}-\mathrm{K}$ partially substituted with organics has increased or maintained the system productivity. It is therefore important that the recommended fertilization either through inorganic fertilizer alone or in combination with manures, crop residue and green manuring has to be promoted in order to maintain long-term rice-wheat system productivity. Nevertheless, there is a need for more quantitative assessment of the carbon sequestration potential of agricultural soils of IGP under different management practices for different climates and agricultural systems by supporting existing long term cropping system and the establishment of new ones where appropriate; quantifying interactions of SOC sequestration and developing soil carbon models that can account for locally relevant agricultural management practices.

\section{References}

Abd El-Fattah, D.A., Ewedab, W.E., Zayed, M.S., Hassaneina, M.K., 2013. Effect of carrier materials, sterilization method, and storage temperature on survival and biological activities of Azotobacter chroococcum inoculants. Ann. Agric. Sci. 58,111-118

Abiven, S., Menasseri, S., Angers, D.A., Leterme, P. 2007. Dynamics of aggregate stability and biological binding agents during decomposition of organic materials. Eur. J. Soil Sci. 58, 239-247.

Abrishamkesh S., Gorji M., and Asadi H. 2011. Long-term effects of land use on soil aggregate stability. Int. Agrophys., 25, 103-
108.

Acosta-Martínez, V., Bell, C.W., Morris, B.E.L., Zak, J. and Allen, V.G. 2010. Long-term soil microbial community and enzyme activity responses to an integrated cropping livestock system in a semi-arid region. Agri, Ecosys Environ.137, 231-240.

Adiningsih, S. J. 1984. Pengarub beberapa factor tarhadap penyediaan Kaluim tanah Sawah daarah Sukabumica dam Bogor. Ph.D. Thesis, IPB, Bogor

Agric. Ecosyst. Environ. 148, 22-28.

Alijani Khadijeh, Mohammad Jafar Bahrani and Seyed Abdolreza Kazemeini. 2012. Shortterm responses of soil and wheat yield to tillage, corn residue management and nitrogen fertilization. Soil Till Res 124:78-82

Amuri, N. and Brye, K.R. 2008. Residue management practice effects on soil penetration in a wheat-soybean double-crop production system. Soil Sci, 173: 779- 791.

Aoyama, M., Angers, D.A., N'Dayegamiye, A. 1999. Particulate and mineral-associated organic matter in water-stable aggregates as affected by mineral fertilizer and manure applications. Can. J. Soil Sci. 79, 295-302

Arthur E., Schjonning P., Moldrup P., and de Jonge L.W., 2012. Soil resistance and resilience to mechanical stresses for three differently managed sandy loam soils. Geoderma, 173-174: 50-60.

Aulakh, M.S., Garg, Ashok Kr. and Kumar, Shrvan. 2013. Impact of Integrated Nutrient, Crop Residue and Tillage Management on Soil Aggregates and Organic Matter Fractions in Semiarid Subtropical Soil under Soybean-Wheat Rotation. Am. J Plant Sci, 4, 2148-2164.

Bandyopadhyay, K.K., Misra, A.K., Ghosh, P.K., Hati, K.M. 2010. Effect of integrated use of farmyard manure and chemical fertilizers on soil physical properties and productivity of soybean.

Bandyopadhyay, P.K., Saha, S., Mani, P.K., Mandal, B. 2010. Effects of organic inputs on aggregate associated organic carbon concentration under long-term rice-wheat cropping system. Geoderma 154,379-386.

Bappa Das,Debashis Chakraborty, Vinod K. Singh, Pramila Aggarwal, Ravender Singh and Brahm S. Dwivedi. 2014. Effect of 
organic inputs on strength and stability of soil aggregates under rice-wheat rotation. Int. Agrophys., 28: 163-168.

Barreto, H. J., and Westerman, R. L. 1989. Soil urease activity in winter wheat residue management system. Soil Sci. Soc. Am. J. 53, 1455-1458.

Bartoli F., Burtin G., and Guerif J., 1992. Influence of organic matter on aggregation in Oxisols rich in gibbsite or ingoethite. II. Clay dispersion, aggregate strength and water stability. Geoderma, 54: 259-274.

Beare, M. H., Cookson, W. R., and Wilson, P. E. 1996. Effects of straw residue management practices on the composition and activity of soil microbial communities and patterns of residue decomposition. In"Proceedings of the ASSS and NZSSS National Soils Conference', pp. 11-12. Melbourne, Australia.

Beesley, L., Inneh, O.S., Norton, G.J., MorenoJimenez, E., Pardo, T., Clemente, R., Dawson, J.J.C. 2014. Assessing the influence of compost and biochar amendments on the mobility and toxicity of metals and arsenic in a naturally contaminated mine soil. Environ. Poll. 186, 195-202.

Benbi, D.K. and Senapati, N. 2010. Soil aggregation and carbon and nitrogen stabilization in relation to residue and manure application in rice-wheat systems in northwest India. Nutr. Cycl. Agro-ecosyst. 87, 233-247.

Berger, L.R., Stamford, N.P., Santos, C.E.R.S., Freitas, A.D.S., Franco, L.O.,Stamford, T.C.M., 2013. J. Soil Sci. Plant Nutr. 13, 592-603.

Beri, V., Sidhu, B. S., Bhat, A. K., and Bhupinder Pal-Singh.1992. Nutrient balance and soil properties as affected by management of crop residues. In" "Proc. Int. Symp. Nutrient Management for Sustained Productivity", (M. S. Bajwa et al., Eds.), Vol. II, pp. 133135. Department of Soils, Punjab Agricultural University, Ludhiana, Punjab, India

Bhattacharya, S.S., Iftikar, W., Sahariah, B., Chattopadhyay, G.N., 2012. Vermicomposting converts fly ash to enrich soil fertility and sustain crop growth in red and lateritic soils. Resour. Conserv. Recycl.
65,100-106.

Bhattacharyya R, Tuti M D, Bisht J K, Bhatt J C, Gupta H S. 2012a. Conservation tillage and fertilization impact on soil aggregation and carbon pools in the Indian Himalayas under an irrigated rice-wheat rotation. Soil Sci 177: 218-228.

Bhattacharyya, R., Kundu, S., Pandey, S.C., Singh, K.P., Gupta, H.S., 2008. Tillage and irrigation effects on crop yields and soil properties under the rice-wheat system in the Indian Himalayas. Agric. Water Manag. 95, 993-1002.

Bhattacharyya,R., Pandey,S.C., Bisht,J.K., Bhatt,J.C.,Gupta, H.S., Tuti, M.D. Mahanta, D., Mina B.L.,Singh, R.D.,Chandra, S., Srivastva, A.K. and Kundu, S. 2013.Tillage and Irrigation Effects on Soil Aggregation and Carbon Pools in the Indian Sub-Himalayas. Agro J.105 (1): 101112

Blanco-Canqui H., Lal R., Owens L.B., Post W.M., and Izaurralde R.C., 2005. Mechanical properties and soil organic carbon of soil aggregates in the northern Appalachians. Soil Sci. Soc. Am. J., 69: 14721481.

Blanco-Canqui, H. and Lal, R. 2007a. Impacts of long-term wheat straw management on soil hydraulic properties under no-tillage. Soil Sci. Soc. Am. J. 71:1166-1173.

Blanco-Canqui, H. and Lal, R. 2008. No-tillage and soil profile carbon sequestration: an onfarm assessment. Soil Sci. Soc. Am. J., 72: 693-701.

Blanco-Canqui, H., Lal, R. 2007. Soil structure and organic carbon relationships following 10 years of wheat straw management in notill. Soil Till. Res. 95, 240-254.

Boopathi M. et al., 2011. Lessons learnt from permanent manurial experiment of Tamilnadu Agricultural University, Coimbatore. Presented at national seminar on "Soil Health Improvement for Enhancing Crop Production" held at the TNAU, Coimbatore, March 17-18, 2011.

Cambardella, C.A. and Elliott,E.T. 1993. Carbon and nitrogen distribution in aggregates from cultivated and native grassland soils. Soil Sci. Soc. Am. J., 57: 1071-1076

Campbell, C.A., Zentner, R.P., Liang, B.C., 
Roloff, G., Gregorich, E.C., Blomer, B., 2000. Organic $C$ accumulation in soil over 30 years in semiarid southwestern Saskatchewan-effect of crop rotations and fertilizers. Can. J. Soil Sci. 80, 179-192.

Carter, M.R., 2002. Soil quality for sustainable land management. Agron. J. 38-47.

Chan, K. Y. 2001. An overview of some tillage impacts on earthworm population abundance and diversity-implications for functioning in soils. Soil Till Res 57: 179- 191.

Chatterjee, A. and Lal, R. 2009. On farm assessment of tillage impact on soil carbon and associated soil quality parameters. Soil Till Res. 104, 270-277.

Chaudhary, T. N., and Ghildyal, B. P. 1969. Aggregate stability of puddled soil during rice growth. J. Indian Soc. Soil Sci. 17, 261.

Chen, H., R. Hou, Y. Gong, H. Li, M. Fan, and Y. Kuzyakov. 2009. Effects of 11 years of conservation tillage on soil organic matter fractions in wheat monoculture in Loess Plateau of China. Soil Tillage Res. 106:8594.

Choudhury Shreyasi Gupta, Sonal Srivastava, Singh Ranbir, Chaudhari S.K., Sharma D.K., Singh S.K., and Sarkar Dipak. 2014. Tillage and residue management effects on soil aggregation, organic carbon dynamics and yield attribute in rice-wheat cropping system under reclaimed sodic soil. Soil Till Res 136: $76-83$

Dalal, R.C., Allen, D. E., Wang, W. J., Reeves, S. and Gibson, I. 2011. Organic carbon and total nitrogen stocks in a Vertisol following 40 years of no-tillage, crop residue retention and nitrogen fertilization. Soil Till Res 12: 133-139.

Das,Bappa., Debashis Chakraborty, Singh,V.K.,Agarwal Pramila, Singh Ravender, and Dwivedi, B.S. 2014. Effect of organic inputs on strength and stability of soil aggregates under rice-wheat rotation. Int. Agrophys., 28, 163-168.

Datta, B., Patruno, A., and Cauazza, L. 1989. Ploughing in straw to concentrate nitrate over 14 years. I. Influence on the structural stability of the soil. Agrochimica 33,1-2

Dexter A.R. and Watts C.W. 2001. Tensile strength and friability. In: Soil and Environmental Analysis. Physical Methods (Eds K.A. Smith,
C.E. Mullins). Dekker Press, New York, USA.

Dexter, A. R., Bein, D., and Hewitt, J. S. 1982. Macro structure of the surface layer of selfmulching clay in relation to cereal stubble management. Soil Till Res. 2, 251-264

Dhiman, S. D., Nandal, D. P., and Om, H. 2000. Productivity of rice (Oryza sativa)-wheat (Triticum aestivum) cropping system as affected by its residue management and fertility levels.

Dhoot, J. S., Singh, N. T., and Brar, S. S. 1974. Polysaccharides in relation to soil aggregation under aerobic and anaerobic conditions. J. Indian Soc. Soil Sci. 22, 217219.

D'Hose, T., Cougnon, M., De Vliegher, A., Vandecasteele, B., Viaene, N., Cornelis, W., Van Bockstaele, E., Reheul, D., 2014. The positive relationship between soil quality and crop production: a case study on the effect of farm compost application. Appl. Soil Ecol. 75, 189-198.

Diana, G., Beni, C. and Marconi, S. 2008. Organic and mineral fertilization: Effects on physical characteristics and boron dynamic in an agricultural soil. Communications in Soil Sci Plant Ana, 39: 1332-1351.

Dikgwatlhe, S.B., Chen, Z., Lal, R., Zhang, H. and Chen, F. 2014. Changes in soil organic carbon and nitrogen as affected by tillage and residue management under wheat-maize cropping system in the North China Plain. Soil Till Res., 144: 110-118.

Doran, J. W. 1980. Soil microbial and biochemical changes associated with reduced tillage. Soil Sci. Soc. Am. J. 44, 765-771.

Dou, F., Wright, A.L. and Hons, F.M. 2008. Sensitivity of labile soil organic carbon to tillage in wheat-based cropping systems. Soil Sci. Soc. Am. J. 72, 1445-1453.

Duiker, S. W., and Lal R. 1999. Crop residue and tillage effects on carbon sequestration in a Luvisol in central Ohio. Soil Till Res, 52, 7381.

Duxbury J M and Lauren J G. 2004. Enhancing technology adoption for the rice-wheat cropping system of the Indo- Gangetic plains.SM-CRSP Annual Report, Soil Management CRSP, University of Hawaii at Manoa, Honolulu, HI. 
Edwards, A.P., Bremner, J.M. 1967. Microaggregates in soils. J. Soil Sci. 18, 64-73.

El Samanoudy, I. M., Askar, F. A., and ElShakweer, M. H. A. 1993. Suitability of natural soil conditioners for improving hydrophysical and chemical properties of alkaline clayey soil. Egyptian J. Soil Sci. 33, 35-45.

Elliott, L. F., and Lynch, J. M. 1984. The effect of available carbon and nitrogen in straw on soil and ash aggregation and acetic acid production. Plant Soil 78, 335-343.

Elmholt P., Schjonning P., Munkholm L.J., and Debosz K. 2008. Soil management effects on aggregate stability Geoderma, 144: 455-467.

Fan, T.L., Stewart, B.A., Yong, W., Luo, J.J., Zhou, G.Y. 2005. Long-term fertilization effects on grain yield, water-use efficiency and soil fertility in the dry-land of Loess Plateau in China. Agric. Ecosyst. Environ. 106, 313-329.

Feng Y S and Li XM. 2001. An analytical model of soil organic carbon dynamics based on a simple "hockey stick" function. Soil Sci. 166: $431-440$.

Fujii, K., Kobayashi, M., and Takahashi, E. 1972. Changes in the soil micro flora and in their metabolic activity. 4. Changes during the decomposition of plant residues. J. Sci. Soil Manure Jap. 43, 155-159.

Fujii, K., Kobayashi, M., Takahashi, E., Suzuki, T., Matsuguchi, T., Araragi, M., and Tanabe, I. 1970. Changes in the soil micro flora and in its metabolic activity. 2. Changes during the decomposition of rice straw added to soil. J. Sci. Soil Manure Jap. 41,323-32.

Galka, B., Labaz, B., Bogacz, A., Bojko, O., Kabala, C.2014.Conversion of Norway spruce forests will reduce organic carbon pools in the mountain soils of SW Poland. Geoderma 213: 287-295.

Gelaw, A.M., Singh, B.R., Lal, R. 2014. Soil organic carbon and total nitrogen stocks under different land uses in a semi-arid watershed in Tigray, Northern Ethiopia. Agric. Ecosyst. Environ. 188, 256-263.

Gershenson, A., Bader, N.E., Cheng, W. 2009. Effects of substrate availability on the temperature sensitivity of soil organic matter decomposition. Global Change Biol. 15, 176 $-183$
Ghimire R, Machad, S, Rhinhart K. 2015. Longterm crop residue and nitrogen management effects on soil profile carbon and nitrogen in wheat-fallow systems. Agron J 107: 22302240.

Ghosh P.K. et al., 2010. Conservation agriculture towards achieving food security in North East India. Current Sci, 99, 915- 921.

Ghosh PK et al., 2010. Conservation agriculture towards achieving food security in North East India. Curr Sci. 99: 915- 921.

Gialhe, H., Din, A. E., and Scherier, A. 1976. The influence of straw, particularly rice straw, in combination with calcium cyanamide on microbiological activity of two Portugese soils. Zant. Bacter. Parast. Infek. Hygn. II 131, 405-418.

Gill, J. S., Khind, C. S., Bijay-Singh, and Yadvinder-Singh. 1998b. Ammonia volatilization under flooded conditions as affected by urease activity of soils amended with crop residues on long-term basis. $J$. Indian Soc. Soil Sci. 46, 448-.450

Gotoh, S., Koga, H., and Ono, S. I. 1984. Effect of long-term application of organic residues on the distribution of organic matter and nitrogen in some rice soil profiles. Soil Sci. Plant Nutr. 30, 273-285.

Govaerts, B., Sayre, K. D., Lichter, K., Dendooven, L. and Deckers, J. 2007. Influence of permanent bed planting and residue management on physical and chemical soil quality in rain fed maize/wheat systems. Plant Soil 291: 39-54.

Govaerts, B., Verhulst, N., Castellanos-Navarrete, A., Sayre, K. D., Dixon, J. and Dendooven, L. 2009. Conservation agriculture and soil carbon sequestration: Between myth and farmer reality. Critical Reviews in Plant Sci, 28: $97-122$.

Goyal S. et al., 1992.Organic matter-microbial biomass relationships in field experiments under tropical conditions: Effects of inorganic fertilization and organic amendments. Soil Biology Biochem, 24, 1081-1084.

Goyal, S., and Chander, K. 1998. Soil microbial biomass and enzyme activities as affected by incorporation of wheat straw in sandy loam. Environ. Ecol. 16, 393-396.

Green, V.S., Stott, D.E., Cruz, J.C., Curi, N., 
2007. Tillage impacts on soil biological activity and aggregation in Brazilian Cerrado Oxisol. Soil Tillage Res. 92:114-121

Guan, S. Y. 1989. Studies on the factors influencing soil enzyme activities: I. Effects of organic manures on soil enzyme activities and $\mathrm{N}$ and $\mathrm{P}$ transformations. Acta Ped. Sinica 26, 72-78.

Hao, Y., Lal, R., Owens, L.B., Lzaurralde, R.C., Post,W.M., Hothem, D.L. 2002. Effect of cropland management and slope position on soil organic carbon pool at the North Appalachian experimental watersheds. Soil Till Res. 68, 133-142.

Harter, J.; H.M.Krause, S. Schuettler, R. Ruser, M. Fromme, T. Scholten, Kappler A.and Behrens, S. 2014. Linking $\mathrm{N}_{2} \mathrm{O}$ emissions from biochar-amended soil to the structure and function of the $\mathrm{N}$-cycling microbial community. ISME J. 8:660-674.

Hemmat, A., Aghilinategh, N., Rezainejad, Y., Sadeghi, M. 2010. Long-term impacts of municipal solid waste compost, sewage sludge and farmyard manure application on organic carbon, bulk density and consistency limits of a calcareous soil in central Iran. Soil Till Res. 108, 43-50.

Huang,S., Peng, X., Huang, Q., Zhang, W. 2010. Soil aggregation and organic carbon fractions affected by long-term fertilization in a red soil of subtropical China. Geoderma 154, 364-369

Indian J. Agron. 45, 1-5.

Jastrow J.D. 1996. Soil aggregate formation and the accrual of particulate and mineralassociated organic matter, Soil Biol. Biochem. 28: 665-676.

Jill M. Motschenbacher, Kristofor R. Brye, Merle M. Anders. 2011. Long-term rice-based cropping system effects on near-surface soil compaction. Agri Sci 2:117-124.

Karamanos, A.J., Bilalia, D. and Sidiras, N. 2004.Effects of reduced tillage and fertilization practices on soil characteristics, plant water status, growth and yield of upland cotton. J Agron Crop Sci, 190: 262276

Karami, A., Homaee, M., Afzalinia, S., Ruhipour, H., Basirat, S. 2012. Organic resource management: impacts on soil aggregate stability and other soil physico-chemical properties.

Kaur, T., Brar, B., Dhillon, N. 2008. Soil organic matter dynamics as affected by long-term use of organic and inorganic fertilizers under maize-wheat cropping system. Nutr. Cycl. Agroecosyst. 81, 59-69.

Kemper W.D., Rosenau R.C. 1986. Aggregate stability and size distribution, in: Methods of Soil Analysis. Part 1. Physical and Mineralogical Methods-Agronomy Monograph No. 9, Society of Agronomy-Soil Sci. Soc. Am. J., pp. 425-442.

Kong, A.Y.Y., Six, J., Bryant, D.C., Dnison, R.F., van Kessel, C. 2005. The relationship between carbon input, aggregation, and soil organic carbon stabilization in sustainable cropping systems. Soil Sci. Soc. Am. J. 69, $1078-1085$.

Król A., Lipiec J., Turski M., and Kuœ J., 2013. Effects of organic and conventional management on physical properties of soil aggregates. Int. Agrophys., 27: 15-21.

Kukal S S, Rasool R and Benbi D K. 2009. Soil organic carbon sequestration in relation to organic and inorganic fertilization in ricewheat and maize-wheat systems.SoilTill. Res.102:87-92.

Kumar Shrvan, Garg Ashok K., and Aulakh M.S. 2016. Effect of Conservation Agriculture Practices on Physical, Chemical and Biological Attributes of Soil Health Under Soybean- Rapeseed Rotation. Agric Res DOI 10.1007/s40003-016-0205-y

Kushwaha, C. P., Tripathi, S. K., and Singh, K. P. 2000. Variations in soil microbial biomass and $\mathrm{N}$ availability due to residue and tillage management in a dryland rice agroecosystem. Soil Till. Res. 56, 153-166.

Ladatko, A. G., and Emtsev, V. T. 1984. The effect of rice straw application on the activity of the anaerobic micro flora in submerged rice field soils. Izvestiya Timiryazevskoi Sel'skokho-zyaistvennoi Akademii 1, 97-103.

Lal, R. 2000. Mulching effects on soil physical quality of an alfisol in western Nigeria. Land Degrad. Dev. 11:383-392.

Lal, R. and Kimble, J.M. 1997. Conservation tillage for carbon sequestration. Nutr. Cycling Agro ecosyst 49:243-253.

Lal, R., J.A. Delgado, J. Gulliford, D. Nielsen, C.W. Rice and R.S. Van Pelt. 2012. Adapting 
agriculture to drought and extreme events. $J$ Soil Water Cons 67 (6):162A-166A.

Lampurlanés, J. and Cantero-Martínez, C. 2003. Soil bulk density and penetration resistance under different tillage and crop management systems and their relation-ship with barley root growth. Agron J, 95: 526-536.

Lewis, D.B., Kaye, J.P., Jabbour, R. and Barbercheck, M.E. 2011. Labile carbon and other soil quality indicators in two tillage systems during transition to organic agriculture. Renewable Agri. Food Sys. 26, 342-353.

Lima, D.L.D., Santos, S.M., Scherer, H.W., Schneider, R.J., Duarte, A.C., Santos, E.B.H., Esteves, V.I. 2009. Effects of organic and inorganic amendments on soil organic matter properties. Geoderma 150, 38-45.

Limon-Ortega, A., Sayre, K. D., Drijber, R. A. and Francis, C. A. 2002. Soil attributes in a furrow-irrigated bed planting system in northwest Mexico. Soil Till Res 63: 123-132.

Lin, C.C., Arun, A.B., Rekha, P.D., Young, C.C., 2008. Application of wastewater from paper and food seasoning industries with green manure to increase soil organic carbon: a laboratory study. Bioresour. Tech. 99: 61906197.

Liu, C. G., and Weng, B. Q. 1991. The function and potential of biofertilizer and organic manure in agricultural production. The new models and research advances in Fujian,China. Regional OYce for Asia and the Pacific (RAPA) Report No. 7, 11-126.

Liu, E., Yan, C., Mei, X., Zhang, Y. and Fan, T. 2013. Long-Term Effect of Manure and Fertilizer on Soil Organic Carbon Pools in Dry-land Farming in Northwest China. PLoS ONE 8(2):56536. doi:10.1371/journal.pone.0056536

Liu, J. R., and Shen, R. P. 1992. The effects of fertilization on the properties and role of soil organic matter. In"Proceedings of International Symposium on Paddy Soils', pp. 246-251.Nanjing, China.

Lou, Y., Xu, M., Chen, X., He, X. and Zhao, K. 2012. Stratification of soil organic $C, N$ and $\mathrm{C}: \mathrm{N}$ ratio as affected by conservation tillage in two maize fields of China. Catena 95:124130.

Lu N., X. Liu, Z. Du, Y.Wang, and Q. Zhang.
2014. The effect of biochar on soil respiration in the maize growing season after 5 years of consecutive application. Soil Res. 52: 505-512.

Lu, F., Wang, X.K., Han, B., Ouyang, Z.Y., Duan, X.N., Zheng, H.U.A. and Miao, H. 2009. Soil carbon se quest rations by nitrogen fertilizer application, straw return and no-tillage in China's cropland. Global Change Biol. 15: 281-305.

Majumder, B., Mandal, B., Bandyopadhyay, P.K.,Gangopadhyay, A., Mani, P.K., Kundu, A.L. and Majumder, D. 2008. Organic amendments influence soil organic carbon pools and crop productivity in 19 years old rice-wheat agro-ecosystems. Soil Sci.Soc. Am. J.72 : 775-785

Mandal, K. G., Mishra, A. K., Hati, K. M., Bandyopadhyay, K. K., Ghosh, P. K. and Mohanty, M. 2004. Rice residue management options and effects on soil properties and crop productivity. Food, Agri Environ, 2 (1): 224-231.

Mandal, U.K., Singh, G., Victor, U.S., Sharma, K.L. 2003. Green manuring: its effect on soil properties and crop growth under rice/wheat cropping system. Eur. J. Agron. 19, 225-237.

Manna, M.C., Swarup, A., Wanjari, R.H., Ravankar, H.N., Mishra, B., Saha, M.N., Singh, Y.V., Sahi, D.K., Sarap, P.A. 2005. Long-term effect of fertilizer and manure application on soil organic carbon storage, soil quality and yield sustainability under sub-humid and semi-arid tropical India. Field Crops Res. 93,264-280.

Mazumdar S.P.; Kundu D.K.; Nayak A.K. and Ghosh Debjani. 2015. Soil Aggregation and Associated Organic Carbon as Affected by Long Term Application of Fertilizer and Organic Manures under Rice-Wheat System in Middle Gangetic Plains of India. Journal of Agricultural Physics, 15 (2): 113-121.

Melero, S., Panettieri, M., Madejo'n, E., Macphersonb, H.G., Morenoa, F.and Murilloa, J.M. 2011. Implementation of chiselling and mouldboard ploughing in soil after 8 years of no-till management in SW, Spain: effect on soil quality. Soil Till Res. 112, 107-113

Mikha, M.M. and Rice, C.W. 2004. Tillage and manure effects on soil and aggregate 
associated carbon and nitrogen. Soil Sci. Soc. Am. J. 68, 809-816

Mikha, M.M., Vigil, M.F. and Benjamin, J.G. 2013. Long-term tillage impacts on soil aggregation and carbon dynamics under wheat-fallow in the Central Great Plains. Soil Sci. Soc. Am. J. 77, 594-605

Mohanty M., Sinha N.K., Hati K.M., Painuli D.K., andChaudhary R.S., 2012. Stability of soil aggregates underdifferent vegetation covers in a vertisol of central India. J. Agric. Physics., 12: 133-142.

Moharana P.C., Sharma B.M., Biswas D.R., Dwivedi B.S., and Singh R.V. 2012. Longterm effect of nutrient management on soil fertility and soil organic carbon pools under a 6-year-old pearl millet-wheat cropping system in an Inceptisol of subtropical India. Field Crops Res 136: 32-41.

Mozumder, P., Berrens, R. 2007. Inorganic fertilizer use and biodiversity risk: an empirical investigation. Ecol. Econ. 62, 538543.

Murphy, D.V., Stockdale, E.A., Brookes, P.C., Goulding, K.W. 2007. Impact of microorganisms on chemical transformations in soil. In: Abbott, L.K., Murphy, D.V. (Eds.), and Soil Biological Fertility-A Key to Sustainable Land Use in Agriculture. Springer, Netherlands, pp. 37-59.

Naklang, K., Whitbread, A., Lefroy, R., Blair, G., Wonprasaid, S., Konboon, Y., and SuriyaArunroj, D. 1999. The management of rice straw, fertilizers and leaf litters in rice cropping systems in northeast Thailand. Plant Soil 209, 21-2.

Naresh R.K.;Gupta Raj K.;Gajendra Pal; Dhaliwal S.S.; Kumar Dipender; Kumar Vineet; Arya Vichitra Kumar; Raju; Singh S.P. ;Basharullah; Singh Onkar. and Kumar Pardeep. 2015. Tillage Crop Establishment Strategies and Soil Fertility Management: Resource Use Efficiencies and Soil Carbon Sequestration in a Rice-Wheat Cropping System. Eco. Env. \& Cons. 21: 121-128.

Naresh, R.K., Gupta, R.K., Minhas, P.S., Rathore, R.S., Dwivedi Ashish, Kumar Mukesh, Tyagi Saurabh, Kumar Vineet, Kumar Pardeep, Purushottam, Kumar Yogesh, Mahajan Nihal Chandra, Kumar Ankit, Bhanu Pratap and Singh Onkar. 2017. Toward Optimal Soil
Organic Carbon Sequestration with effects of Agricultural Management Practices and Climate Change in Upland Soils of Subtropical India: A Review. Int.J. Chem. Stu. 5 (2): 433-442

Naresh, R.K., S.P. Singh, and P. Chauhan. 2012. Influence of conservation agriculture, permanent raised bed planting and residue management on soil quality and productivity in maize-wheat system in western Uttar Pradesh. Int. J. Life Sc. BT \& Pharm. Res 1 (4):27-34.

Naresh, R.K.,Gupta Raj K., Jat, M.L., Singh,S.P., Dwivedi Ashish, Dhaliwal, S.S., Kumar Vineet, Kumar Lalit, Singh Onkar, Singh Vikrant, Kumar Ashok and Rathore, R.S. 2016. Tillage, irrigation levels and rice straw mulches effects on wheat productivity, soil aggregates and soil organic carbon dynamics after rice in sandy loam soils of subtropical climatic conditions. J. PURE APPL MICROBIO, 10 (3): 1987-2002

Niggli, U.; Fließbach, A.; Hepperly, P. and Scialabba, N.2009. Low greenhouse gas agriculture: Mitigation and adaptation potential of sustainable farming systems, Rev. 2. Rome, FAO

Nugroho, S. G., and Kuwatsuka, S. 1992a. Concurrent observation of several processes of nitrogen metabolism in soil amended with organic materials. III. Changes in microbial populations following application of ammonium-nitrogen. Soil Sci. Plant Nutr. 38,601-610.

Nugroho, S. G., and Kuwatsuka, S. 1992b. Concurrent observation of several processes of nitrogen metabolism in soil amended with organic materials. IV. Regulatory effects of ammonium- and nitrate-nitrogen on denitrification and $\mathrm{N}_{2}$ fixation. Soil Sci. Plant Nutr. 38, 611-617.

Ono, S. 1989. Nitrogen mineralization from paddy and upland soils under flooded and non flooded incubation. Soil Sci. Plant Nutr. 35, 417-428.

Pandey D, Agrawal M, Singh Bohra J, Adhya T K, Bhattacharyya P. 2014. Recalcitrant and labile carbon pools in a sub-humid tropical soil under different tillage combinations: A case study of rice-wheat system. Soil Tillage Res143: 116-122. 
Paudel Madhab, Sah Shrawan Kumar, Andrew McDonald, and Chaudhary Narendra Kumar. 2014. Soil Organic Carbon Sequestration in Rice-Wheat System under Conservation and Conventional Agriculture in Western Chitwan, Nepal. World J Agri Res 2, (6A): 15

Paustian, K., Collins, H. P., and Paul, E. A. 1997. Management controls on soil carbon. In "Soil Organic Matter Agro-ecosystems: LongTerm Experiments in North America"' (E. A. Paul, K. Paustian, E. T. Elliott, and C. V. Cole, Eds.), pp. 15-49. CRC Press, Boca Raton, FL.

Pinheiro, E. F. M., Pereira, M. G. and Anjos, L. H. C.2004. Aggregate distribution and soil organic matter under different tillage systems for vegetable crops in a red latosol from Brazil. Soil Till Res. 77, 79-84.

Plante, A.F., McGill, W.B., 2002a. Soil aggregate dynamics and the retention of organic matter in laboratory-incubated soil with differing simulated tillage frequencies. Soil Till. Res. 66, 79-92.

Ponnamperuma, F. N. 1984. Straw as a source of nutrients for wetland rice. In "Organic Matter and Rice”, pp. 117-135. Int. Rice Res. Institute, Los Banos, Philippines

Prasad, R., and Power, J. F. 1991. Crop residue management. Adv Soil Sci. 15, 205-239.

Puget P and Drinkwater L E. 2001. Short-term dynamics of root- and shoot-derived carbon from a leguminous green manure. Soil Sci. Soc. Am. J., 65: 771-779.

Raju, R. A., and Reddy, M. N. 2000. Integrated management of green leaf, compost, cropresidues and inorganic fertilizers in rice (Oryza, sativa) - rice system. Indian $J$. Agron.45,629-635.

Rao, D.L.N. 2007. Microbial Diversity, Soil Health and Sustainability. J. Indian Soc Soil Sci, 55, 392-403.

Rao, D.L.N. and Burns, R.G. 1990. The effect of surface growth of blue green algae and bryophytes on some microbiological, biochemical and physical soil properties. Bio Fertility Soils 9: 239-244.

Rao, D.L.N. and Manna, M.C. 2005. An Appraisal of Soil Quality Assessment Indicators In Abrol IP et al., (Eds). Conservation Agriculture- Status and
Prospects. Proc. National Conference on Conservation Agriculture: Conserving Resources-Enhancing Productivity. CASA, New Delhi, pp 210-217.

Raverkar, K.P., Gupta, S.B., Ajay and Rao, D.L.N. 2005. Survival of soybean rhizobia in summer and proliferation during monsoon in Vertisols of central India. J Ind Soc Soil Sci, 53: 591-597.

Razafimbelo TM.,Albrecht A., Oliver R.,Chevallier T., Chapuis-Lardy L. and Feller C. 2008. Aggregate associated-C and physical protection in a tropical clayey soil under Malagasy conventional and no-tillage systems. Soil Till. Res. 98: 140-149

Reddy, K.S., Singh, M., Tripathi, A.K., Saha, M.N. 2013. Changes in amount of organic and inorganic fractions of nitrogen in an Eutrochrept soil after long-term cropping with different fertilizer and organic manure inputs. J. Plant Nutr. Soil Sci. 166, 232-238.

Rupela, O.P., Gowda, C.L.L., Wani, S.P., Bee, H. 2005. Evaluation of crop production systems based on locally-available biological inputs. In: Uphoff $\mathrm{N}$ (ed) Biological approaches to sustainable soil systems. CRC Press, Boca Raton, Florida, USA, 501-515.

Sa, J. C. M., C.C. Cerri, W.A. Dick, R. Lal, S.P. Venske Filho, M.C. Piccolo and B.E. Feigl. 2001. Organic matter dynamics and carbon sequestration rates for a tillage Chronosequence on a Brazilian oxisol. Soil Sci. Soc. Am. J. 65: 1486-1499

Saikia, P., Bhattacharya, S.S., Baruah, K.K. 2015. Organic substitution in fertilizer schedule: impacts on soil health, photosynthetic efficiency, yield and assimilation in wheat grown in alluvial soil. Agric. Ecosyst. Environ. 203, 102-109.

Salinas-Garcia, J.R., Hons, F.M. and Matocha, J.E.1997. Long-term effects of tillage and fertilization on soil organic matter dynamics. Soil Sci. Soc. Am. J., 61: 152-159.

Schjonning P., Christensen B.T., and Carstensen B., 1994.Physical and chemical properties of a sandy loam soil receiving animal manure, mineral fertilizer or no fertilizer for 90 years. Eur. J. Soil Sci., 45: 257-268.

Schjønning, P., de Jonge, L.W., Munkholm, L.J., Moldrup, P., Christensen, B.T., Olesen, J.E. 2012. Clay dispersibility and soil friability- 
testing the soil clay-to-carbon saturation concept. Vadose Zone J.11,http://dx.doi.org/10.2136/vzj2011.0067

Schjønning, P., Munkholm, L.J., Elmholt, S., Olsen, J.E. 2007. Organic matter and soil tilth in arable farming: management makes a difference within 5-6 years. Agric. Ecosyst. Environ. 122, 157-172.

Sepehya S., Subehia S.K., Rana S.S., Negi S.C. 2012. Effect of integrated nutrient management on rice-wheat yield and soil properties in a north western Himalayan region. Indian J Soil Conser, 40 (2) : 135140

Sharma, P., Singh Geeta,Rana, P. Singh., 2011.Conservation tillage, optimal water and organic nutrient supply enhance soil microbial activities during wheat (Triticum aestivum L.) cultivation. Brazilian $J$. Microbiology, 42, 531-542.

Sharma, S. N. 2001. Effect of residue management practices and nitrogen rates on chemical properties of soil in a rice (Oryza sativa)-wheat (Triticum aestivum) cropping system. Indian J. Agric. Sci. 71, 293-295.

Shrestha, B.M., Singh, B.R., Sitaula, B.K., Lal, R., Bajracharya, R.M. 2007. Soil aggregate and particle-associated organic carbon under different land uses in Nepal. Soil Sci. Soc. Am. J. 71, 1194-1203.

Šimanský V, Tobiašová E, Chlpík J. 2008. Soil tillage and fertilization of Orthic Luvisol and their influence on chemical properties, soil structure stability and carbon distribution in water-stable macro-aggregates. Soil Till. Res. 100: 125-132.

Singh Y. and Sidhu H.S.2014. Management of Cereal Crop Residues for Sustainable RiceWheat Production System in the IndoGangetic Plains of India. Proc Indian Natn Sci Acad. 80: 95-114

Singh, G., Jalota, S.K. and Singh, Y. 2007. Manuring and residue management effects on physical properties of a soil under the ricewheat system in Punjab. Soil Till. Res. 94: 229-238.

Singh, Y. 2011. Crop residue management for improving soil and crop productivity. In: A. R. Sharma and U. K. Behera (eds). Resource conserving techniques in crop production (pp. 166-189). Scientific publishers, India.
Six J., Elliott E.T., Paustian K. 1999. Aggregate and soil organic matter dynamics under conventional and no-tillage systems. Soil Sci. Soc. Am. J. 63:1350-1358.

Six J., Elliott E.T., Paustian K., Doran J.W. 1998. Aggregation and soil organic matter accumulation in cultivated and native grassland soils. Soil Sci. Soc. Am. J. 62:1367-1377.

Six J.,Elliott E.T.,Paustian K. 2000.Soil macroaggregate turnover and micro-aggregate formation: A mechanism for $\mathrm{C}$ sequestration under no-tillage agriculture, Soil Biol. Biochem. 32: 2099-2103.

Six J.,Paustian K., Elliott E.T., Combrink C. 2000. Soil structure and organic matter: I. Distribution of aggregate-size classes and aggregate-associated carbon. Soil Sci. Soc. Am. J. 64: 681-689.

Six, J., Conant, R. T., Paul, E. A. and. Paustian, K. 2000b. Stabilization mechanisms of soil organic matter: Implications for C-saturation of soils. Plant Soil 241:155-176.

Six, J., Feller, C., Denef, K., Ogle, S.M., De Moraes, J.C. and Albrecht, A. 2000. Soil organic matter, biota and aggregation in temperate and tropical soils- effects of notillage. Agronomie. 22: 755-775.

Six, J., Ogle, S. M., Breidt, F. J., Conant, R. T., Mosier, A. R. and Paustian, K. 2004. The potential to mitigate global warming with notillage management is only realized when practised in the long term. Glob. Change Biol. 10: 155-160.

Smith K., Cumby T., Lapworth J., Misselbrook,T. and Williams, A.2007. Natural crusting of slurry storage as an abatement measure for ammonia emissions on dairy farms. Biosystems Engg, 97: 464-471.

Soil Till. Res. 110,115-125

Son, Y., Yang, S.Y., Jun, Y.C., Kim, R.H., Lee, Y.Y., Hwang, J.O. and Kim, J.S. 2003. Soil carbon and nitrogen dynamics during conversion of agricultural lands to natural vegetation in central Korea. Communications in Soil Science and Plant Analysis, 34: 15111527.

Song,Ke., Jianjun Yang, Yong Xue, Weiguang Lv, Xianqing Zheng and Jianjun Pan. 2016. Influence of tillage practices and straw incorporation on soil aggregates, organic 
carbon, and crop yields in a rice-wheat rotation system. Scientific Reports | 6:36602 | DOI: 10.1038/srep36602

Srinivasan, V., Maheswarappa, H. P. and Lal, R.2012. Long term effects of topsoil depth and amendments on particulate and non particulate carbon fractions in a Miamian soil of Central Ohio. Soil Till Res. 121, 10-17.

Stott, D. E., and Martin, J. P. 1989. Organic matter decomposition and retention in arid soils. Arid Soil Res. Rehabil. 3, 115-148.

Sun, G., Xu, S., Zhang, H., Chen, F. and Xiao, X. 2010. Effects of rotational tillage in double rice cropping region on organic carbon storage of the arable paddy soil.Sci. Agric. Sin. 43: 3776-3783

Tian, G., Brussard, L., and Kang, B. T. 1993. Biological effects of plant residues with contrasting chemical compositions under humid tropical conditions-effects on soil fauna. Soil Biol. Biochem. 25, 731-737.

Tian, G., Brussard, L., and Kang, B. T. 1995. An index for assessing the quality of plant residues and evaluating their effects on soil and crop in the (sub-) humid tropics. Appl. Soil Ecol. 2, 25-32.

Tian, G., Kang, B. T., and Brussaard, L. 1992. Biological effects of plant residues with contrasting chemical compositions under humid tropical conditions-decomposition and nutrient release. Soil Biol. Biochem. 24, $1051-1060$

Tisdall, J.M., and J.M. Oades. 1979. Stabilization of soil aggregates by the root systems of ryegrass. Aust. J. Soil Res. 17:429-441.

Tisdall, J.M., Oades, J.M.1982. Organic matter and water-stable aggregates in soils. J. Soil Sci. 62, 141-163.

Turski M., 2002. Influence of the physical properties of soil aggregates for the growth of wheat plant in initial development phase (in Polish). Acta Agrophysica, 78: 263-269.

Van Den Bossche, A., De Bolle, S., De Neve, S., Hofman, G. 2009. Effect of tillage intensity on $\mathrm{N}$ mineralization of different crop residues in a temperate climate. Soil Till Res 103, 316-324.

Verhulst, N., Govaerts, B., Verachtert, E., Castellanos-Navarrete, A., Mezzalama, M., Wall, P., Decker, J. and Sayre, K.D. 2010.Conservation agriculture, improving soil quality for sustainable production systems? In: Lal, R., Stewart, B.A. (Eds.), Advances in Soil Science: Food Security and Soil Quality. CRC Press, Boca Raton, FL, USA, pp. 137-208.

Verma N. K. and Pandey B. K. 2013. Effect of Varying Rice Residue Management Practices on Growth and Yield of Wheat and Soil Organic Carbon in Rice-Wheat Sequence. Global J Sci Frontier Res. 13 (3): 1-8.

Verma,T.S. and Bhagat, R.M.1992. Impact of rice straw management practices on yield, nitrogen uptake and soil properties in a wheat rice rotation in northern India. Fertilizer Res, 33, 97-106.

Wander M.M., Yang X. 2000. Influence of tillage on the dynamics of loose and occluded particulate and humified organic matter fractions. Soil Biol. Biochem. 32: 1151-1160.

Wander, M.M., Traina, S.J., Stinner, B.R. and Peters, S.E. 1994. Organic and conventional management effects on biologically active soil organic matter pools. Soil Sci. Soc. Am. J., 58: 1130-1139

Wang, J., Li, X. and Zhu, A., 2012. Effects of tillage and residue management on soil microbial communities in North China. Plant, Soil Environ 58: 28-33.

Wang, J.G. and Bakken, L.R. 1997b. Competition for nitrogen during mineralization of plant residues in soil: microbial response to $\mathrm{C}$ and N availability. Soil Biol. Biochem. 29, 163170.

Wardle, D. A. 1995. Impact of disturbance on detritus food-webs in agro-ecosystems of contrasting tillage and weed management practices. Adv. Ecological Res. 26, 105-185

Waring, B.G., Averill, C. and Hawkes, C.V. 2013. Differences in fungal and bacterial physiology alter soil carbon and nitrogen cycling: insights from meta-analysis and theoretical models. Eco Letters 16: 887-894.

Watts C.W. and Dexter A.R., 1998. Soil friability: Theory, measurement and the effects of management practices and organic carbon content. Eur. J. Soil Sci., 49: 73-84.

Weber, J., Karczewska, A., Drozd, J., Licznar, M., Licznar, S., Jamroz, E., Kocowicz, A. 2007. Agricultural and ecological aspects of a sandy soil as affected by the application of municipal solid waste composts. Soil Biol. 
Biochem. 39,1294-1302.

Whalen J K and Chang C.2002. Macro-aggregate characteristics in cultivated soils after 25 annual manure applications. Soil Sci. Soc. Am. J. 66: 1637 - 1647.

Wilhelm, W.W., Johnson, J.M.F., Hatfield, J.L., Voorhees, W.B. and Linden, D.R., Crop and soil productivity response to corn residue removal: an alternative view. Agron J., 96: $1-17$.

Wu, F., Z. Jia, S.Wang, S. Chang, and A. Startsev. 2013. Contrasting effects of wheat straw and its biochar on greenhouse gas emissions and enzyme activities in a Chernozemic soil. Biol. Fertil. Soils. 49:555-565.

Wuest, S. 2014. Seasonal variation in soil organic carbon. Soil Sci. Soc. Am. J. 78: 1442-1447.

Xu, Y., Chen, W. and Shen, Q. 2007. Soil organic car-bon and nitrogen pools impacted by longterm tillage and fertilization practices. Communications Soil Sci Plant Anal, 38: 347-357.

Xue, J., Pua, C., Liua, S., Chena, Z., Chena, F., Xiaob, X., Lalc, R., Zhanga, H. 2015. Effects of tillage systems on soil organic carbon and total nitrogen in a double paddy cropping system in Southern China. Soil Tillage Res. 153: 161-168.

Yadvinder-Singh, Bijay-Singh, Ladha, J. K., Khind, C. S., Gupta, R. K., Meelu, O. P., and Pasuquin, E. 2004a. Long-term effects of integrated management of organic inputs on yield and soil fertility in the rice-wheat rotation. Soil Sci. Soc. Am. J. (in press).

Yadvinder-Singh, Bijay-Singh, Ladha, J. K., Khind, C. S., Khera, T. S., and Bueno, C. S. 2004b. Effects of residue decomposition on productivity and soil fertility in rice-wheat rotation. Soil Sci. Soc. Am. J. 68, 854-864

Yang, Z.P., Zheng, S.X., Nie, J., Liao, Y.L., Xie, J. 2014. Effects of long-term winter planted green manure on distribution and storage of organic carbon and nitrogen in water-stable aggregates of reddish paddy soil under a double-rice cropping system. J. Integ. Agric. 13:1772-1781.

Zhang Q., X.Wang, Z.Du, X. Liu, and Y.Wang. 2013a. Impact of biochar on nitrate accumulation in an alkaline soil. Soil Res. 51:521-52.

Zhang, S., Lovdahl, L., Tong, Y., Yang, X., and Wang, Q. 2009.Effects of mulching and catch cropping on temperature, soil moisture and wheat yield on the Loess Plateau of China. Soil Till Res. 102: 78-86.

Zhang, X. R., Li, H. W., He, J., Wang, Q. J. and Golabi, M. H.2009. Influence of conservation tillage practices on soil properties and crop yields for maize and wheat cultivation in Beijing, China. Australian J Soil Res. 47: 362-371.

\section{How to cite this article:}

Naresh, R.K., A.S. Panwar, S.S. Dhaliwal, R.K. Gupta, Arvind Kumar, R.S. Rathore, Ashok Kumar, Dipender Kumar, Mohan Lal, Sunil Kumar, Saurabh Tyagi, Vineet Kumar, S.P. Singh, Vikrant Singh and Nihal Chandra Mahajan. 2017. Effect of Organic Inputs on Strength and Stability of Soil Aggregates Associated Organic Carbon Concentration under Rice-Wheat Rotation in Indo-Gangetic Plain Zone of India. Int.J.Curr.Microbiol.App.Sci. 6(10): 1973-2008. doi: https://doi.org/10.20546/ijcmas.2017.610.237 